\title{
Seismic structural assessment of the Christchurch Catholic Basilica, New
}

\section{Zealand}

Luís C. Silva, ${ }^{1}$ Nuno Mendes, ${ }^{2}$ Paulo B. Lourenço, ${ }^{3}$ Jason Ingham ${ }^{4}$

${ }^{1} \mathrm{PhD}$ candidate, ISISE, Department of Civil Engineering, University of Minho, Azurém, 4800-

058 Guimarães, Portugal. E-mail: luisilva.civil@gmail.com

2 Post-Doctoral Researcher, ISISE, Department of Civil Engineering, University of Minho, Azurém, 4800-058 Guimarães, Portugal. E-mail: nunomendes@ civil.uminho.pt

${ }^{3}$ Full Professor, ISISE, Department of Civil Engineering, University of Minho, Azurém, 4800058 Guimarães, Portugal. E-mail: pbl@civil.uminho.pt

${ }^{4}$ Full Professor, Department of Civil and Environmental Engineering, University of Auckland, Auckland, New Zealand. Email: j.ingham@auckland.ac.nz

\begin{abstract}
An evaluation of the seismic performance of the Christchurch Catholic Basilica, New Zealand, also known as the Cathedral of the Blessed Sacrament, is presented. The cultural importance of the Basilica has been recognized, as it is listed as a Category I building on the New Zealand heritage register. Four strong earthquakes that occurred between September 2010 and June 2011 caused progressive damage and local collapse in the Basilica. Numerical analyses were performed to allow a seismic assessment of the Basilica using the Finite Element Method. A macro-modelling approach following homogenization concepts was considered and the seismic behaviour of the structure was evaluated through pushover analysis with the distribution of forces being proportional to the mass. The analyses allowed damage patterns and capacity curves to be determined, and identified the most vulnerable elements, the maximum load capacity, and the expected collapse mechanisms. Furthermore, a comparison between the numerical output and the existing crack patterns was undertaken, and good agreement was obtained. Finally, two strengthening techniques were evaluated with the aim of reducing the seismic vulnerability of the structure by avoiding collapse of the most vulnerable structural elements.
\end{abstract}

Keywords-Basilica, Christchurch, Seismic assessment, FE modelling, Pushover analysis 


\section{$1 \quad 1 \quad$ Introduction}

2 Cultural heritage buildings include structures that represent a set of particular values

3 that symbolically allow them to become part of a given identity and continuity [1].

4 Nowadays, the conservation principles and recommendations of the international council

5 on monuments and sites (hereafter, ICOMOS) [2] aim to guarantee that the identity and

6 significance of heritage buildings will be safeguarded. These guidelines are the outcome

7 of centuries of ideological evolution, including aesthetic and technical issues [3], [4].

8 Presented herein is an assessment of the seismic performance of the Cathedral of the

9 Blessed Sacrament, also known as the Christchurch Catholic Basilica. The Basilica is

10 listed as a Category I building on the New Zealand (NZ) heritage register ("special or

11 outstanding historical or cultural significance or value") [5] and was subject to a

12 strengthening intervention in 2004. Its safety level was assumed to be adequate then, but,

13 a sequence of earthquakes caused progressive damage and local collapses. Four main seismic events occurring over a period of nine months were identified, being: (i) on the 4

September 2010; (ii) on the 26 December 2010; (iii) on the 22 February 2011; and (iv) on the 13 June 2011. Recognising the symbolism and type of loss associated with this Basilica, the presented study aimed to represent a contribution to the conservation and restoration of cultural heritage buildings, enrich the literature in the field and demonstrate the capability of current advanced analysis tools for engineering applications.

The scope of the research is particularly relevant if one notes that the lack of prompt action has been indicated as the main cause of collapse of important cultural heritage buildings, for instance St Marco's Campanile in Venice (Italy) in 1902, the Civic Tower of Pavia (Italy) in 1989, and St Martinus Church in Kerksken (Belgium) in 1990 [6]. It is known that existing UnReinforced Masonry (URM) buildings present a high seismic vulnerability [7]. This vulnerability can be attributed to: (i) poor out-of-plane capacity, 
which is directly associated with the low tensile strength of URM; (ii) a lack of capacity to dissipate energy; (iii) the absence of seismic requirements at the time of construction [7], [8]; (iv) a lack of proper connections between structural elements [9]; (v) flexibility of the floors [10]; and (vi) deterioration of materials over time [11].

The process of intervention in these constructions is complex due to the lack of structural information and their high importance. A scientifically based intervention is less susceptible to inadequate actions and thus, in order to avoid damaging measures, the adopted methodology should be incremental, including studies such as an historical literature review, inspections, monitoring actions, and structural analysis [12], [13]. In this way, an intervention should be carried out after a careful diagnosis and evaluation of the safety of the structure in its present state, as defined in the ICOMOS principles [14]. In the evaluation of safety, numerical modelling is a valuable contribution to assess the structural behaviour of historical buildings.

There are several approaches and types of analysis that can be used to evaluate the behaviour of masonry structures. The differences are mainly related to assumptions about used nowadays.

Limit analysis based on the kinematic approach is also a very practical and effective tool 
51 due to the difficulty of obtaining the material properties [18]. Indeed, macro-block approaches, based on the rocking of monolithic walls, allow the collapse load factor of structures to be estimated [19]-[22]. However, an expert-based decision approach is required for each study case in order to correctly ascertain the potential collapse mechanisms [22]. Advanced finite element (FE) analysis makes it possible to easily combine modelling strategies and material constitutive models. In fact, the classic FE models, usually prepared based on micro-modelling and macro-modelling approaches, provide accurate results [23], [24]. In the micro-modelling approaches, all the masonry components (units, mortar, and unit/mortar interface) are separately discretized, leading to models with a larger number of degrees of freedom and consequently a need for high computational efforts [25], [26]. Macro-modelling considers masonry as a continuum and homogeneous material in which isotropic or anisotropic behaviour can be adopted [27]. This modelling approach has been used with success in the analysis of large masonry structures, as shown in [28]-[30], and is assumed here.

The outline of the paper is described next. First, a brief description related to the location, the main structural features of the Cathedral, and preparation of the FE numerical model is presented. The FE model was prepared using the software DIANA [31], assuming that the masonry is a continuous and homogeneous material (macro-modelling). Pushover analysis with a horizontal load distribution proportional to the mass was adopted to evaluate the seismic response of the structure. In the comparison between the numerical and real behaviour, the damage pattern, collapse mechanisms, and maximum load capacity were adopted.

Finally, two strengthening interventions are evaluated, aiming at avoiding local collapses and taking into account the requirements (ultimate limit state) defined in the seismic code of NZ (NZS 1170 [32]). 


\section{Cathedral of the Blessed Sacrament}

\subsection{Description of the structure}

The Cathedral of the Blessed Sacrament (see Fig. 1) was designed by the architect Francis William Petre. The Cathedral is based on Roman style, in which the typical features of the arrangement, that is, a nave, a transept, chapels, an apse, a dome, and bell towers are presented. The Basilica was built in only four years, between 1901 and 1905, using Oamaru limestone. The Basilica has, in plan, a length of $62 \mathrm{~m}$ (north and south directions) and a width of $27 \mathrm{~m}$ (west and east directions). The highest element is the dome, with a height of $36 \mathrm{~m}$, followed by the two bell towers, which are $32 \mathrm{~m}$ in height (see Fig. 2). The walls were built with two-leaf stone masonry and a concrete core in the middle. The stones are linked through grout-filled cavities and have a thickness of about $50 \mathrm{~cm}$. The internal and external claddings have a thickness of $12.5 \mathrm{~cm}$ of limestone [33]. The thickness of the concrete core is equal to $20 \mathrm{~cm}$. The domes are copper lined and the main dome is supported by four large arches, made from no-fines concrete, that spring from four large piers at the first-floor level with an internal spiral above [33]. The main dome is located above the sanctuary, which is not a common feature of this type of church: usually, the main dome is located at the crossing of the transepts and nave. The nave contains colonnades with diverse capitals and spacious arcades.

In order to assure an appropriate seismic behaviour, a structural study was performed in 2002, adopting simplified analyses and practical engineering judgement [33]. Based on this study, a strengthening intervention was carried out, which involved: (i) new reinforced concrete $(\mathrm{RC})$ slabs with a thickness of $10 \mathrm{~cm}$ at the first-floor and roof levels, aiming at providing a box-behaviour with rigid diaphragms; (ii) steel ties with a diameter of $3.2 \mathrm{~cm}$ and RC ring-beams with a cross section of $20 \times 60 \mathrm{~cm}^{2}$ at the two bell towers, above and below the window openings; (iii) RC ring beams with sections of $20 \times 60 \mathrm{~cm}^{2}$ 
at the top of the main dome, above and below the windows; (iv) post-tensioning at alternate columns of the nave colonnade; (v) grouting of external parapets and ornaments; and (vi) attachment of the gable ends of the roof, the transepts, and ornaments [33]. The adopted techniques focused on the weakest elements of the building. The building response was improved to reach the required standard values for lateral load capacity with a Peak Ground Acceleration (PGA) equal to $0.05 \mathrm{~g}$ ( $g$ is the gravitational acceleration) [33]. An intervention based on empirical methods increased the lateral strength for a value of about $45 \%$ of the strength required by the code, which represents $33 \%$ of the required value defined by the current code [33]. It is noted that the intervention was designed based on the code NZS 1170 [32].

\subsection{Damage survey}

112 The description of the observed damage is presented below for each seismic event

113 considered. It is important to note that as part of the Christchurch array of seismic 114 recording stations, the accelerometer station designated as CCCC [34] was located only $11520 \mathrm{~m}$ from the Basilica. This fact, which is not very common, allowed meaningful 116 conclusions to be drawn about both the registered PGA and the accelerogram acting at 117 the base of the Basilica structure. Nevertheless, some attention is required when comparing the recorded ground motions at the site against the demands specified by current seismic design standards [32], because the design spectra values can be biased if soil-structure interaction influences the ground motion characteristics, mainly in the range of long period, as reported in [35] for the studied series of earthquakes.

122 The first earthquake occurred in the early morning of 4 September 2010 with a moment magnitude of $\mathrm{M}_{\mathrm{W}}$ 7.1. The epicentre was located near Darfield town, a region of Canterbury located $40 \mathrm{~km}$ west of Christchurch [36], [37]. The peak geometric mean horizontal ground motion acceleration (PGA) registered at the CCCC station was equal 
to $0.22 \mathrm{~g}$ [38], with the peak vertical PGA component being $0.15 \mathrm{~g}$ [38]. The earthquake caused some damage to the Christchurch Catholic Basilica [33]. The walls were affected by minor cracking as well as significant movements in the stones of the west sacristy wall and out-of-plane movements in the middle column of the north bell tower (eastern elevation). Despite that, cracks were also observed in retrofitted elements, such as the underside of the first-floor diaphragm all around the nave and the main dome, in the form of shear cracks at the joints [33], [39]. After the visual survey, the building was tagged with a red placard, which prohibited its usage [40].

The earthquake of 22 February 2011 presented a moment magnitude of $\mathrm{M}_{\mathrm{W}}$ 6.3. The horizontal geometric mean PGA at the CCCC station was equal to $0.43 \mathrm{~g}$ [41] and the PGA of the vertical component was $0.69 \mathrm{~g}$. This vertical component of the recorded ground motion was very significant when compared with the observed value for the September 2010 earthquake, and this earthquake resulted in severe damage to the Basilica, with several structural elements collapsing.

The most important damage observed after the seismic event of February 2011 is described as follows (Fig. 3) [33], [39], [42]: (i) damage at the north and south tower belfries, with collapse in the northwest and southwest directions, respectively; (ii) the north and south façades present severe shear cracking behind the bell towers, spalling of the ground piers (due to in-plane rocking), and high deformations and cracking around the windows and doors; (iii) cracking of the outward walls of the north and south transepts; the north wall had a shear crack around one window on the ground level, which is not significant compared to the south façade; (iv) significant damage at the main dome drum, as well as collapse of the supporting north arch and severe damage at the south $\operatorname{arch}$ (v) in the two levels that include the sanctuary, below the Dome and Rotunda, some 
concrete flat roof areas of the upper level (retrofitted in 2004) collapsed and present severe shear cracks.

Aftershocks occurred on 13 June 2011 and induced further damage in the buildings, which were already vulnerable after the main earthquakes of September 2010 and February 2011 [43]. In the case of the Christchurch Catholic Basilica, besides the increase of the severity of the existing damage, these events led to a need to change the prior strategies for removal of the main dome [33].

\section{Numerical model}

\subsection{FE model preparation}

The FE numerical model was prepared using the software TNO DIANA [28], assuming that the masonry is a continuous and homogeneous material (macro-modelling). The geometric definition has a key role in the modelling process. A thorough and detailed geometry construction is likely to provide better results. Ideally, a sophisticated threedimensional model composed of solid FEs only and with a fine refinement level would better represent all the Basilica's features. However, such a strategy would require a considerable effort in the preparation of the mesh as well as in-depth knowledge and observation, and such analyses are very time consuming. Thus, a simplified geometry that can represent the main structural features should be adopted. In this context, aiming at reducing the structural global number of degrees of freedom of the Basilica's numerical model, beam, shell and solid finite elements were used, see Fig. 4a.

170 All the structural members that present an axial length much larger than the dimensions 171 of its transversal section were modelled using beam elements. A two-node threedimensional elements were adopted, called L12BE (6 DOF), based on Bernoulli theory [31]. This element set includes all the interior beams, the west, north, and south porch columns, the interior colonnades of the nave and altar, and the steel cross braces and RC 
ring beams added to the bell towers in the 2004 strengthening intervention. Note that the existing three-dimensional frames of the interior dome $\left(5 \times 10 \mathrm{~cm}^{2}\right)$, the Basilica's main dome $\left(10 \times 30 \mathrm{~cm}^{2}\right)$, and the nave roofs (diameter $\left.=10 \mathrm{~cm}\right)$ were also modelled using beam elements. It is noted that whilst the latter systems correctly represent the load paths, the claddings associated with these parts were not explicitly modelled. Instead, representative point masses (PT3T [31]) were computed for each node located at the top of these threedimensional frames (nodes which receive the cladding self-weight) according to its tributary area (Fig. 4d.)

Another adopted strategy was the use of shell FEs to represent geometric parts where the thickness was small in comparison to the other two planar dimensions, as depicted in Fig. 4a). Three-dimensional curved elements based on Mindlin-Reissner theory were assumed to simulate all the façades considered as load-bearing walls, the interior walls, the arcades, the RC slab of the first floor that surrounds the Basilica's nave and the sacristy, the exterior RC slab above the sacristy, and the RC slabs of the bell towers. The adopted triangular (T15SH) and quadrilateral (Q20SH) shell elements present linear interpolation $[31]$.

Finally, although it is a cumbersome task to model the elements above the sacristy as solid FEs, this procedure was adopted because a representative structural arrangement using shell or beam elements would have be difficult to idealize and the reliability of the approach would have required careful analysis. Hence, the four piers and arches, as well as the interior rotunda walls and main dome structure, were modelled with solid elements (see Fig. 4(a)). For solid elements, brick (hexahedral HX24L) and wedge (tetrahedral TP18L) elements were used [31]. Regarding the boundary conditions, all the degrees of freedom were restrained, namely at the base of the four piers, the masonry walls, and the columns. 
200 The final mesh of the Basilica's model is presented in Fig. 4c. The priority was to achieve a regular and mapped type of discretization with an average size dimension of $150 \mathrm{~mm}$. However, this algorithm was not always possible to be fulfilled especially in the sacristy elements and at its vicinity. Thus, the use of wedge solid elements and triangular shell elements, with a more refinement level, has been considered in some cases to better embody the geometry details and guarantee the mesh compatibility between the adjoining elements. The final model, presented in Fig. 4(b), has a total of 36,758 elements, in which 1,720 are beam elements, 27,919 are quadrilateral shell elements, 235 are triangular shell elements, 5,661 are brick elements, and 1,223 are wedge elements. The total number of degrees of freedom is 178,719 .

\subsection{Material properties}

To represent the physical nonlinear behaviour, a total-strain fixed crack model was adopted [31]. This approach makes it possible to describe the tensile, compression, and shear nonlinear behaviour for a continuum model. Failure is initiated when the principal stresses reach the maximum allowable (material tensile strength) stress, being the cracks orthogonal to the principal stresses direction. The initial cracking orientation is maintained as fixed despite the possible variation of the principal stresses direction during

217 the loading process (see [31], [44]). Such assumption follows, in fact, the physical nature of cracking. A shear retention value has been defined as 0.1 . The diagrams that represent each material in terms of stress-strain relationship were also defined. In the present case study, only masonry and concrete elements are assumed to have material nonlinearity and its behaviour given by a parabolic stress-strain relationship for compression and an exponential stress-strain relationship for tension behaviour, see Fig. 5.

The material and mechanical properties are presented in Table 1. Bear that, although the values used for the masonry refer to the equivalent homogeneous material, a unit-cell 
homogenized strategy was not employed. Instead, information provided by the NZ authorities and from literature [45], such as the Young's modulus and compressive strength of masonry units and reinforced concrete, was considered in the preparation of the numerical model. For the inelastic parameters, the recommendations in the literature were adopted [46], [47]. In this regard, the complex morphology of the masonry cross section was not accounted and, therefore, the possibility of occurring a disaggregation between each leaf of the walls implicitly disregarded.

The existence of transversal steel connectors between the three-leaf masonry walls [33] and the failure modes of the Basilica observed after the occurrence of the seismic events (belfry towers collapse) can, in part, support the assumption of a monolithic behaviour of the walls. This approach is also used effectively in other studies ([6]-[8], [43], [48]-[53] where the obtained failure modes of related URM buildings tend to be governed by its geometrical features, within mechanisms formed by the movement of macro-elements, rather than by a local wall leaf disaggregation. Thus, it is expectable that a macroscopic approach, using a simplified (yet realistic) equivalent masonry material with a low tensile strength, can capture well the global damage and allow to draw the more prone to occur failure mechanisms.

After the earthquakes of 4 September 2010 and 22 February 2011, dynamic identification tests were carried out to estimate the mode shapes and frequencies of the Basilica [39]. The experimental modes present very complex mode shapes, due to the severe existing damage and local effects, and were not considered. Instead, a non-damaged model was

246 considered for the seismic analysis and to understand the damage observed.

247 At last, it is important to refer that a modal dynamic identification has been performed 248 after the earthquakes of 4 September 2010 and 22 February 2011. The data retrieved by this dynamic test can be useful to calibrate the elastic material properties of the structure. 
However, as addressed in the damage survey section, the Basilica suffered severe damage with occurrence of several partial collapses after the seismic events. Therefore, a calibration process of the elastic material properties requires the insertion of the reported damage within the Basilica's numerical model. This task was develop in detail in [51] and a calibration between the numerical and experimental modal frequencies and shapes was concluded to be a hard and non-objective task. In fact, three points can support the decision of non-consideration of the damaged modal data in the present study: (1) the limited number of accelerometers used in the dynamic identification tests make impossible a better description of the damaged structure of the Basilica; (2) safety recommendations led to the use of a flying drone [69] to observe the interior damage of the Basilica, meaning the possibility that not all the damage has been collected; (3) the insertion of numerical damage (via a stiffness material reduction or by thickness decrease of shells) is always debatable and might lack real representativeness.

\subsection{Linear analysis for gravitational loads}

A linear static analysis of the Christchurch Catholic Basilica for the gravitational loads was performed, aiming at evaluating the mesh of the model, the displacements, and the stress concentrations. Fig. 6(a) presents the structural deformation, in which it is

267 observed that the maximum displacement is approximately equal to $8 \mathrm{~mm}$ and occurs in the solid elements, that is, elements above the sanctuary. It is also noted that larger displacements occur in the second-floor slabs that are connected to the rotunda walls. The vertical stresses (see Fig. 6(b)) show that the maximum compressive value is equal to $1.8 \mathrm{MPa}$ and occurs at the base of the altar piers for masonry. A peak value of the

272 compressive stresses is also located at the connection of the west façade columns (1.1

$273 \mathrm{MPa}$ ). The maximum compressive stress in the base of the bell towers is equal to $0.8 \mathrm{MPa}$. 
274 The values of compressive and tensile principal stresses for masonry elements are equal 275 to 1.8 and $0.02 \mathrm{MPa}$, respectively.

276 In general, the compressive and tensile stresses for the RC slabs are equal to 2.0 and $0.2 \mathrm{MPa}$, respectively. The maximum stresses are located around the base and at the top of the sacristy arches, namely between the connections of beam elements from the nave, RC slabs, and solid elements. The maximum principal compressive stress on the RC slabs is approximately $10 \mathrm{MPa}$, which corresponds to about one third of the compressive RC strength. The maximum principal tensile stress is $0.8 \mathrm{MPa}$, which is a reasonably high value. It is frequent that in sharp corners, in point loading systems (as the connection between a beam element and a shell), when an abrupt load transition between different element types (as the present case) or among other cases [54], a stress singularity or concentration can occur [55]. Still, the value is lower than the expected tensile strength of concrete and $\mathrm{RC}$ elements present reinforcement steel bars that provide the expected tensile strength.

\subsection{Eigenvalue analysis}

An eigenvalue analysis was also performed to obtain the numerical frequencies and mode shapes of the undamaged structure. The first six global frequencies range from $2.92 \mathrm{~Hz}$ (period of $0.34 \mathrm{~s}$ ) to $5.84 \mathrm{~Hz}$ (period of $0.17 \mathrm{~s}$ ). Bearing the first 100 modes, a cumulative mass participation of about $85 \%$ in each horizontal direction was obtained. The high number of modes is due to local modes on the roof trusses of the nave and main 294 dome.

295 The first six global mode shapes are presented in Fig. 7. The first mode corresponds to a global transversal mode $(2.92 \mathrm{~Hz})$. The maximum modal displacements occur in the main dome, bell towers, and west and nave façades. Due to the considerable stiffness of the sacristy piers, the surrounding façade walls present minor modal displacements than the 
ones located in the nave. The second, third, fourth, and fifth modes are characterized mainly by movements of the bell towers. In general, from the first six modes it can be concluded that: (i) the bell towers, main dome, and nave façades are the more flexible elements as well as the more relevant elements for the Basilica's dynamic behaviour; and (ii) the bell towers are slightly more vulnerable in the higher global inertial direction 304 (longitudinal direction).

\section{Pushover Analysis}

The current codes guidelines permit the use of both nonlinear-static (pushover) and dynamic strategies in a seismic assessment of a given structure, see [32], [56]-[59]. It is 
The adoption of such uniform load pattern can, depending on the case study, lead to some misrepresentation of the capacity when compared with a modal pushover analysis [60]. The latter deviations tend to be relatively more important in cases where higher mode effects can be influential in the structures behaviour [61], [62]. Yet, following the recommendations of the New Zealand guidelines [63], such effect is not likely to be significant when the mass participation of the first mode is, in a given direction, equal or higher to $60 \%$. The participation modal masses (first two modes) described in Fig. 7 corroborates the latter, which supports the strategy considered. Furthermore, being a nonadaptive method, it allows to follow a more straightforward approach and within an 
that such modelling assumption is valid and the results, in terms of derived numerical damage and seismic capacity found, not so different from the ones accounting with a damaged model.

Secondly, the consideration of vertical components in the numerical modelling is still an open discussion since the association of existing damage as an direct effect of vertical motions is difficult to carry on [69]. Although vertical accelerations are typically much lower than its horizontal counterparts (unless of near field ground motions) and thus not the main cause of damage to structures it does not mean that they are not important. In the present study, the vertical PGA of the February 2011 earthquake is significant and could have an implication in the obtained damage of the Basilica. This can decrease the pre-compression states of the Basilica structural parts and consequently increase the possibility of shear induced damage to occur more easily due to the horizontal accelerations. Nevertheless, due to numerical convenience reasons, these have been disregarded in the seismic assessment of the Basilica. Still, it is important to highlight the awareness on the potential repercussion of this choice, i.e. the retrieved structural seismic capacity can be non-conservative.

\subsection{Adopted numerical controls}

The seismic performance of the Cathedral was evaluated through a pushover analysis. The seismic forces are considered by applying a horizontal and monotonically increasing load on the structure after application of the self-weight (vertical load). The horizontal load-step was initially defined to be equal to 0.01 , meaning that the structure

370 is subjected to a total lateral load of $1 \%$ of its self-weight at each step. Once material nonlinearity is being considered for both masonry and RC elements, a quasi-Newton iterative method improved with an arc-length procedure and a line search algorithm was defined. This procedure intends to correctly catch the capacity curve post-peak by solving 
snap-back and snap-through numerical related issues within a load step, by changing the displacement-based increment associated, see [70] for further details regarding the arclength method. A convergence energy-based criterion equal to $1.0 \times 10^{-3}$ [31] was adopted. The numerical simulations stopped when the latter criterion was not respected which does not necessarily mean that a collapse has occurred but, given the very large displacements and extensive damage present in the model, were considered satisfactory.

\subsection{Longitudinal direction $+\mathrm{X}$}

The control nodes assumed for the pushover analysis in the longitudinal direction $+\mathrm{X}$ are located at the west tympanum wall (node 1), at the top of the main dome (node 2), and at the top of the bell tower (node 3) (Fig. 8). The capacity curves are presented in Fig. 9. All the control nodes have a marked nonlinear behaviour, in which the linear limit (onset of cracking) occurs for a load factor of about $20 \%$ of the gravity acceleration $(0.20$ g). The top of the tympanum west wall (node 1) has a larger horizontal displacement than the main dome node (node 2) and the bell tower node (node 3). A maximum horizontal load of about $66 \%$ of the structure self-weight $(0.66 \mathrm{~g})$ was applied.

The behaviour and damage assessment of the structure for the seismic events of both September 2010 and February 2011 was assessed by considering the applied horizontal load to be equal to the registered PGA values [34] of the Christchurch recording station (see Section 2.2). The maximum displacement is $23 \mathrm{~mm}$ for the September earthquake (node 1, 2 and 3) and $69 \mathrm{~mm}$ (node 1) for the February 2011 earthquake; see Fig. 9(a). For both earthquakes, the larger displacements are located on the top of the elements. However, the horizontal relative displacements do not present a linear increase in elevation. The first-floor walls present a significant in-plane displacement (and damage), which is observed from the inter-storey drifts and the deformed shape of the bell tower (Fig. 9(b)). 
399 The principal tensile strains that occurred in the south façade are in agreement with the 400 displacement-based results. For a PGA of $0.22 \mathrm{~g}$, which represents the seismic event of 401 September 2010, minor cracks are observed around the first-floor openings. However, for 402 a PGA of $0.43 \mathrm{~g}$, the severity of the damage increases (Fig. 10). It is observed that the 403 damage, caused by in-plane shear stress, is concentrated in the first-floor walls, that is, in 404 the openings and the wall connections (shell elements). The latter is especially observed in the bell towers. In fact, the elements added in the 2004 strengthening works, namely the RC slabs in the bell towers and nave, as well as the steel braces and ring beams of the third floor of the bell tower, improve the seismic behaviour of the structure (see Fig. 9). However, once no strengthening measures were considered at the first floor, the damage tends to be localized at these masonry walls (as depicted in Fig. 10).

410 The west tympanum wall presents horizontal cracks at the top of the RC slab 411 reinforcement. This damage is in agreement with the expected failure mode of this type 412 of element, which causes a rotation line and consequently out-of-plane rocking of the 413 tympanum. In the solid elements, the piers present maximum principal compressive 414 stresses of 2.5 and $6.5 \mathrm{MPa}$ at the piers-arches connection for PGA values of 0.22 and $4150.43 \mathrm{~g}$, respectively. Failure by crushing of the piers at the base does not occur for either 416 PGA value (stress value lower than the compressive strength of the masonry). However, 417 for both seismic events, horizontal cracks are expected at both the base and the top of the 418 piers as a result of the rotation of these elements. The rotunda also presents damage, 419 namely shear cracks in the north and south walls. The damage is more severe near the second-floor opening that provides a passage between the interior arches and exterior 421 balcony. 


\subsection{Longitudinal direction $-\mathrm{X}$}

In the pushover analysis in the longitudinal direction $-X$, the control nodes 1,2 , and 3 were considered. The capacity curves (Fig. 11) show that the west tympanum wall (node 1) and the bell towers (node 3) are the most vulnerable elements found in this analysis. The last elements have a marked nonlinear behaviour, in which the linear limit (initial cracking) occurs for a load factor of about $15 \%$. The maximum horizontal load factor applied in this analysis is equal to $0.35 \mathrm{~g}$ due to convergence issues. For this load level the west façade tympanum and the bell towers reach their maximum load capacities (nodes 1 and 3), causing difficulties in the solution convergence of the system equilibrium equations. The results show that the west gable wall and the bell towers have lower strength capacity in the $-\mathrm{X}$ direction. This can be explained by the confinement action caused by the rotunda walls, which occurs in the $+\mathrm{X}$ direction (the confinement is only possible due to the modelled roof trusses). This behaviour does not occur for the $-\mathrm{X}$ direction, because the out-of-plane movement of the west façade tympanum leads to tensile stresses that cannot be withstood by the rotunda walls, due to the low tensile strength of masonry elements.

438 On the basis of the deformed shape and drifts presented in Fig. 11, it can be concluded that the relative inter-storey displacements of the bell towers are higher at the first and second stories. However, the horizontal displacement that occurred at the top of the bell towers is greater ( $97 \mathrm{~mm}$, in comparison to $\approx 55 \mathrm{~mm}$ ), even for a lower load level. This is explained by the inelastic behaviour of the structure, which is lower in the $+\mathrm{X}$ direction.

The crack pattern is similar to the damage obtained in the pushover analysis in the $+X$ direction, that is, a high concentration of cracks in the north and south walls (nave and sacristy) near the openings (Fig. 12). The longitudinal façades present damage caused by in-plane shear stresses. Therefore, the main difference in the in-plane behaviour of the 
447 longitudinal façades found in the pushover analysis in the $+X$ and $-X$ direction 448 corresponds to the way in which diagonal shear cracks propagate. It is also important to

449 refer to another difference in the damage pattern, highlighted in Fig. 12 by a dashed circle,

450 which corresponds to the damage at the connection between the south nave and south 451 stairwell wall. This is not related to a shear action but is instead caused by the pushover 452 action in these elements (tensile stresses). Thus, if the pushover analysis in the $+\mathrm{X}$ direction causes moderate damage in the bell tower walls, the pushover analysis in the -

$\mathrm{X}$ direction creates a crack pattern prone to an out-of-plane failure mechanism.

\subsection{Transversal direction $+Y$}

In the pushover analysis in the transversal $+\mathrm{Y}$ direction, different control nodes were used, namely nodes 4 and 5 , since they correspond to nodes located in elements that exhibit the maximum horizontal displacement in this direction (see Fig. 8). The capacity curves show that the outset of cracking, which leads to the decrease of the initial stiffness, occurs for a lateral load value that ranges from 15 to $20 \%$ of the self-weight (Fig. 13(a)).

Thus, the vulnerable elements of the structure are the bell towers. It is also observed that the main dome (node 2, according to Fig. 8b) presents the lowest horizontal displacement. The main damage obtained in the pushover analysis in the $+Y$ direction is presented in Fig. 14. The damage pattern is similar, as expected, for the horizontal load equal to 0.22 $\mathrm{g}$ (September 2010 earthquake) and $0.45 \mathrm{~g}$ (approximately equal to the PGA of the February 2011 earthquake). Nevertheless, the structure presents low damage for the load coefficient of $22 \%$ of the self-weight and thus only the damage that occurs for a horizontal load equal to $0.45 \mathrm{~g}$ is presented.

Fig. 14(a) shows that the concentration of tensile stresses occurs at the top of the connection between the façade and the north bell tower. A set of diagonal cracks is also observed in Fig. 14(b), due to in-plane shear stresses near the openings of the west and 
east elevations and near the wall connections, mainly in the transversal walls of the transepts and in the second floor of the east wall. The Basilica also presents cracking at the second-floor slab near the east rotunda wall, as well as damage at the south, east, and west rotunda walls (Fig. 14(b)). The same type of damage also occurs in the four large piers, which present horizontal cracking due to tensile stresses caused by the outward movement (bending).

Furthermore, diagonal shear cracks are very clear in the transversal walls of the south and north façades. There is no occurrence of toe crushing and, similarly to what occurs in pushover analyses in the longitudinal direction, the difference between displacements of the first and second storeys is considerable, being the main cause of the concentration of shear cracks at the first floor of both bell tower walls. In addition to the damage already reported, there is a lower capacity to dissipate energy in the transversal direction, and the transversal interior walls present damage (Fig. 14(c)).

\subsection{Results and discussion}

From the results of the nonlinear static analyses it is possible to put forward several final remarks about the structural behaviour of the Christchurch Catholic Basilica in response to seismic loads. The pushover analyses allowed the crack patterns and failure mechanisms to be obtained and several in-plane and out-of-plane mechanisms were observed. The areas with concentration of damage are the two bell towers, the interior and transept walls transversally positioned, the top of the west gable wall, the north and south walls of the rotunda, the west wall of the sacristy, and the second-floor RC slab near to the rotunda walls. Furthermore, cracks were observed near the openings throughout all the external façades of the structure, at the interior walls, and in the RC slabs. 
The damage obtained in the four piers is caused by tensile stresses due to the bending behaviour. The piers do not present high displacements at the top in any of the analyses. The main reason for this limited displacement can be related to: (i) their high stiffness, which leads to lower horizontal displacements at the top (it is noted that the slenderness ratio of the piers is approximately equal to three [height/transversal dimension, considering only the first floor]), see Fig. 4a; and (ii) the existence of interior transversal walls indirectly connected with these piers, see Fig. 14(c), that have a structural important out-of-plane role. Finally, with the exception of the base of the elements, the main dome walls do not present any relevant damage (Fig. 14(b)), which leads to the conclusion that the action of the RC ring beams is effective. In general, it is possible to conclude that the damage obtained from the numerical model is in good agreement with the observed crack pattern after the series of earthquakes. The model also indicates that the structure is unsafe for an earthquake such as the one experienced, so significant damage would be expected and thus likely the occurrence of a local collapse, particularly of the bell towers.

\section{Strengthening proposals}

This section presents two strengthening proposals to be implemented in the

512 Cathedral, taking into account the strengthening intervention of 2004. The goal is to

513 guarantee the ultimate limit state (ULS), that is, to prevent collapse of structural elements

514 for the highest mean horizontal PGA recorded in the 2010 and 2011 earthquakes. Thus,

515 the value assigned as performance reference for the structural assessment is given by

$516 \quad 0.43 \mathrm{~g}$ and is defined by the February 2011 seismic event (it corresponds to a period of return around 400 years for new buildings design according to [32]). The NZS 1170 was revised after these seismic events and the updated version states that the strength of a damaged structure must be re-established at $33 \%$ of the full requirements of the code for new structures [33]. 
521 Based on the principles of the New Zealand Committee of ICOMOS, there is an inevitable concern regarding buildings with cultural and historical value, and interventions should be carried out only after a careful analysis, in order to avoid collapse and minimize intervention works [14].

Several strategies can be adopted to improve the seismic capacity of the Basilica. In general, the strengthening solutions could include the improvement of material properties, through grout injection [71] or mortar repointing [72]; the reduction of torsion effects by the confinement of structural elements in order to obtain better in-plane and out-of-plane seismic behaviour of the masonry wall; and the improvement of connections between wraps on piers to improve the in-plane shear and bending behaviour [75], [76], are reasonable solutions. The two strengthening interventions proposed in this study are are applied to the structure at the level of the floors being anchored in the slabs. The aim is to improve the connection between orthogonal walls, allowing a better force distribution into the nave walls and preventing out-of-plane collapse of the bell towers. concerns, because it is reversible and brings minimal constraints and architectural

542 interferences. The concern about corrosion is also overcome by using stainless steel tie rods. This intervention includes the application of seven stainless steel tie rods (class AISI 316L) with a diameter of $32 \mathrm{~mm}$, divided into two levels, in each tower (Fig. 16(a)). The 
545 ties are anchored through steel plates or anchor bolts in the slabs (third level) and wall

546 (second level).

547 The axial design force of the steel tie beams was derived from the concept of limit analysis

548 bearing the bell towers overturning mechanism from Fig. 15a [77]. The ties may assure

549 the masonry towers equilibrium for, at least, a lateral load capacity of $0.43 \mathrm{~g}$, i.e. the

550 assumed reference value. The maximum allowable tie stress is given by the elastic

551 resistance defined by the design steel grade (yield tensile strength of $190 \mathrm{MPa}$ ) [78]. The

552 dimensions of the plates were designed to avoid failure of: (i) the steel components, i.e.

553 punching of the plate [78] ; and (ii) failure by masonry pull-out, i.e. the so-called masonry

554 cone-breakout according to [79]. Note that the design of the latter systems is an iterative

555 procedure, meaning that the design force was verified and validated after performing the

556 quasi-static analysis.

\section{$557 \quad 5.2 \quad$ Strengthening proposal 2}

558 The second strengthening proposal keeps the three tie rods of the first proposal at

559 the main façade but includes ring beams at the bell towers instead of the stainless-steel

560 tie rods (Fig. 16(b)). The design of the steel tie beams and respective anchor plates follow

561 the same guidelines used for the first strengthening scheme. For the rings, after

562 conducting several quasi-static analyses with different cross-section dimensions, stainless

563 steel channels with a height of $180 \mathrm{~mm}$ (class AISI 316L) were used. These allowed to

564 achieve the intended behaviour of the bell towers confinement and are a reasonable

565 choice, according to the authors experience. The stresses found in the connection of the

566 ring beams are far from the ultimate design ones, according to [78]. Yet, it may be

567 remarked that it is assumed that its steel members should be welded to guarantee a

568 monolithic frame (rigid connections). Its connection with the walls may be accomplished

569 [74], [80]: (i) in the inner side of the wall, through inclined stainless steel anchorages; or 
(ii) at both the inner and outer sides of the walls, through threaded rods inside a grouted

duct. The goal is to improve the connection between structural elements, namely the bell towers and nave walls. Furthermore, it allows confinement of the bell towers in order to facilitate a better force distribution and prevent out-of-plane collapse.

\subsection{Results and discussion}

The efficiency of the strengthening proposals was evaluated based on pushover analysis. Only the pushover analysis in the longitudinal direction $-\mathrm{X}$ was performed (outof-plane mechanism of bell towers and main façade with lowest load capacity). The capacity curves (Fig. 17(a)) show a clear improvement in the load and inelastic displacement capacity of the structure, for which at least a maximum horizontal load of about $0.57 \mathrm{~g}$ was obtained (strengthening proposal 2). The strengthening proposal 1 presented at least a maximum horizontal load equal to $0.49 \mathrm{~g}$. It is noted that the maximum horizontal load applied to the non-strengthened model is equal to $0.35 \mathrm{~g}$.

In what concerns the crack pattern of the non-strengthened model, the Basilica suffered severe damage to both bell towers and the vicinity walls for a horizontal load of $0.35 \mathrm{~g}$ (Fig. 18(a)). Extensive cracking due to in-plane shear failure is observed (note that that the strain values shown are too large, indicating a fully formed mechanism. At this stage large displacements and large strains should be considered but this does not affect the conclusions obtained or the peak capacity values). The bell tower presents a maximum principal strain of 0.0598 around the first storey window, which can activate the out-ofplane failure mechanism observed after the earthquakes (see Fig. 3b). It is expected that the interventions could prevent the formation of the later failure mechanism and thus the bell towers collapse. Fig. 18(b) and (c) show that the results are in accordance with what was expected, with insignificant damage being observed at the bell tower walls. Hence, 
the strengthening measures distribute the loads to the nave walls and nave slabs, causing more damage to these elements, namely some cracks in the first floor of the nave.

596 Considerable differences in the damage to the interior walls are also presented. In the non-strengthened structure (Fig. 19(a)), the occurrence of damage in the interior walls and second-floor slab is clear. However, the severity of the damage decreases significantly for the strengthened models; see Fig. 19(b) (the results for the two interventions are similar).

601 Finally, the seismic performance of the structure with the strengthening proposals incorporated was also evaluated for a horizontal load equal to $0.43 \mathrm{~g}$, which represents the PGA of the February 2010 earthquake. Fig. 20 presents the principal tensile strains, from which it can be observed that the first strengthening model suffers more damage than the strengthening model 2. Moderate damage is also present in the first floor, with severe cracking around the openings, which is a pattern of damage similar to the obtained with the unstrengthen model in Fig. 18a. Some crack is also visible in the second floor, which it is explained by the difference in stiffness of the elements, mainly due to the RC bond beams added at the third floor. Thus, the strengthening proposal 1 is an effective

610 solution as it creates new loads paths and delays failure. However, it does not provide 611 sufficient strengthening to change the condition of the bell towers as the most vulnerable 612 elements.

613 With respect to the second intervention, a better behaviour is obtained. In fact, the use of 614 steel rings between openings makes it possible to achieve a better monolithic behaviour 615 by better transferring forces into the nave walls (stiffer walls in the longitudinal direction). 616 This leads to considerably lower inter-storey displacements and a smooth deformed shape 617 (Fig. 17(b)). Minor cracking is also observed in the strengthened model 2, similarly to the strengthened model 1 , leading to the conclusion that the 12-m-long ties anchored to the 
619 slab at the second level are efficient (see the crack line with an inclination of $45^{\circ}$ on the 620 second floor of the nave in Fig. 17(b)).

\section{Conclusions}

Seismic assessment was conducted and vulnerability reduction of the Christchurch

Catholic Basilica (New Zealand) was studied. The earthquake sequence of 2011 caused severe damage to the Basilica's structure and an FE model of the Christchurch Catholic Basilica was subsequently prepared based on the macro-modelling approach. The seismic assessment was performed using a non-calibrated FE model of the Basilica through pushover analysis in order to compare the results with the observed damage. Three pushover analyses were carried out $( \pm X$ and $+Y)$, in which the material properties were defined based on the recommendations from the literature and NZ authorities.

From the results of the pushover analyses, it could be concluded that the transversal direction corresponds to the most vulnerable direction of the structure. Furthermore, from the pushover analysis in the longitudinal direction $-X$, it could be concluded that the bell towers are the most vulnerable elements of the structure.

The structural strengthening undertaken in 2004 played a decisive role in the avoidance of further damage, but this strengthening was insufficient to prevent local failure mechanisms. The numerical results indicate that the structure is unsafe for an earthquake such as the one experienced in February 2011, in which the collapse of the bell towers and significant damage would be expected.

The model allowed the identification of two possible strengthening solutions that could

640 change the outcome of similar seismic events to be addressed. The solutions adopted

641 follow the criteria of reversibility and low invasiveness recommended by ICOMOS [14].

642 The results show that both strengthening interventions improve the Basilica's behaviour.

643 The second strengthening proposal, which includes stainless steel rings, presents the best 
644 seismic performance, guaranteeing a safety level of the bell towers of at least $40 \%$ of the 645 full code requirements [33].

646 Still, such safety levels have been found using as basis the undamaged model of the

647 Basilica. The goal was to assess the expected damage, if this intervention has been carried 648 out before the occurrence of the seismic events. It would be an interesting exercise to 649 draw conclusions if the intervention works have been conducted after the seismic events 650 occurrence, however: (i) the damage caused by the September 2010 earthquake is not so 651 relevant to change, by itself, the conclusions addressed upon the non-damage model. In 652 fact, the latter observation also supports the followed assumption of performing the 653 seismic assessment of the Basilica through quasi-static analysis on the non-damaged 654 model; (ii) the February 2011 earthquake led, apart from extensive moderate to severe cracking in the Basilica, to the collapse of both bell towers. The latter goes against the initial proposed goal of the strengthening interventions, i.e. avoid the collapse of these elements.

658 Furthermore, from the results obtained in this study, the following conclusions could be 659 drawn: (i) The first and second floors of the bell towers show a difference in stiffness 660 from the third one, and thus the strengthening elements should be added along the bell 661 tower's height in order to avoid stiffness discontinuities. (ii) A considerable difference in 662 the stiffness properties of the materials used (compatibility problems) is not 663 recommended. This aspect was also stated in [33] and is mainly related to the added RC 664 beams. (iii) A good connection between elements must be guaranteed to improve the 665 distribution of horizontal loads. The so-called box behaviour, which is presented in the 666 numerical model of the Basilica, also plays a decisive role. The diaphragm effect is not 667 common in historical constructions [60] but has an important effect in the maintenance 668 of the stability of the façades. The rigid diaphragms avoid out-of-plane collapse 
mechanisms of walls; (iv) The formation of mechanisms is recommended, with the aim

670 of overcoming the low shear and tensile strength of masonry, as demonstrated by the 671 proposed intervention solutions.

\section{$672 \quad 7 \quad$ Acknowledgements}

673 The authors thank Opus International Consultants Limited, Christchurch, and Dr João 674 Leite, former PhD student at the University of Minho, for the information made available 675 to prepare the model.

\section{References}

677 [1] Sir Bernard M. Feilden, Conservation of Historic Buildings, 3rd ed. London: Butterworth-Heinemann, 2003.

[2] ICOMOS, "International Charter for the Conservation and Restoration of Monuments and Sites (The Venice Charter)," in Ind International Congress of

[4] P. Roca, "The study and restoration of historical structures: From principles to

[5] ChristChurch City Council, "Heritage Listings." . high stress levels," Eng. Struct., vol. 33, no. 1, pp. 210-217, Jan. 2011. Earthq. Eng., vol. 4, no. 4, pp. 445-463, Sep. 2006.

L. F. Ramos and P. B. Lourenço, "Modeling and vulnerability of historical city 1295-1310, Jul. 2004. 
694 [9] M. Bruneau, "Seismic evaluation of unreinforced masonry buildings - a state-of695 the-art report," Can. J. Civ. Eng., vol. 21, pp. 512-539, 1994.

696 [10] N. Mendes, P. B. Lourenço, and A. Campos-Costa, "Shaking table testing of an existing masonry building: assessment and improvement of the seismic performance," Earthq. Eng. Struct. Dyn., vol. 43, no. 2, pp. 247-266, Feb. 2014.

[11] R. Cardoso, M. Lopes, and R. Bento, "Seismic evaluation of old masonry 700 buildings. Part I: Method description and application to a case-study," Eng. Struct., vol. 27, no. 14, pp. 2024-2035, Dec. 2005.

[12] G. Croci, The conservation and structural restoration of architectural heritage. Southampton: Computational Mechanics Publications, 1998.

[13] L. Binda, A. Saisi, and C. Tiraboschi, "Investigation procedures for the diagnosis 705 of historic masonries," Constr. Build. Mater., vol. 14, no. 4, pp. 199-233, Jun. 2000.

[14] ICOMOS Recommendations, "International Council on Monument and sites, Recommendation for the analysis, conservation and Structural restoration of Architectural Heritage.” Barcelona, 2005.

[15] P. B. Lourenço, "Computations on historic masonry structures," Prog. Struct. Eng. Mater., vol. 4, no. 3, pp. 301-319, Jul. 2002.

[16] J. Heyman, “The stone skeleton," Int. J. Solids Struct., vol. 2, no. 2, pp. 249-279, Apr. 1966.

[17] A. Giuffrè and C. Carocci, "Statica e dinamica delle costruzioni murarie storiche," in Atti del Convegno internazionale CNR "Le pietre da costruzione: il tufo calcareo e la pietra leccese,” 1993, pp. 539-598.

[18] A. Orduña, "Seismic assessment of ancient masonry structures by rigid blocks limit analysis," University of Minho, 2003. 
[19] A. Orduña and P. B. Lourenço, "Three-dimensional limit analysis of rigid blocks assemblages. Part I: Torsion failure on frictional interfaces and limit analysis formulation,” Int. J. Solids Struct., vol. 42, no. 18-19, pp. 5140-5160, Sep. 2005.

[20] M. Gilbert, C. Casapulla, and H. M. Ahmed, "Limit analysis of masonry block structures with non-associative frictional joints using linear programming," Comput. Struct., vol. 84, no. 13-14, pp. 873-887, May 2006.

[21] G. de Felice, "Out-of-Plane Seismic Capacity of Masonry Depending on Wall Section Morphology,” Int. J. Archit. Herit., vol. 5, no. 4-5, pp. 466-482, Jul. 2011.

[22] N. Mendes, "Masonry Macro-block Analysis," in Encyclopedia of Earthquake Engineering, Berlin, Heidelberg: Springer Berlin Heidelberg, 2014, pp. 1-10.

[23] P. B. Lourenço, "Structural masonry analysis: recent developments and prospects," in Proceedings of the 14th International brick and block masonry conference, 2008.

[24] P. Roca, M. Cervera, G. Gariup, and L. Pela', "Structural Analysis of Masonry Historical Constructions. Classical and Advanced Approaches," Arch. Comput. Methods Eng., vol. 17, no. 3, pp. 299-325, Jul. 2010.

[25] P. B. Lourenço and J. G. Rots, "Multisurface Interface Model for Analysis of Masonry Structures,” J. Eng. Mech., vol. 123, no. 7, pp. 660-668, Jul. 1997.

[26] S. Pietruszczak and R. Ushaksaraei, "Description of inelastic behaviour of structural masonry,” Int. J. Solids Struct., vol. 40, no. 15, pp. 4003-4019, Jul. 2003.

[27] P. B. Lourenço, J. G. Rots, and J. Blaauwendraad, "Continuum Model for Masonry: Parameter Estimation and Validation,” J. Struct. Eng., vol. 124, no. 6, pp. 642-652, Jun. 1998.

[28] Lourenço, K. J. Krakowiak, F. M. Fernandes, and L. F. Ramos, "Failure analysis of Monastery of Jerónimos, Lisbon: How to learn from sophisticated numerical 
models," Eng. Fail. Anal., vol. 14, no. 2, pp. 280-300, Mar. 2007.

[29] A. Araujo, "Seismic Assessment of St James Church by Means of Pushover Analysis - Before and After the New Zealand Earthquake," TOCIEJ Open Civ. Eng. J., vol. 6, no. 1, 2012.

[30] R. Marques, J. M. Pereira, P. B. Lourenço, W. Parker, and M. Uno, "Study of the Seismic Behavior of the 'Old Municipal Chambers' Building in Christchurch, New Zealand," J. Earthq. Eng., vol. 17, no. 3, pp. 350-377, Mar. 2013.

[31] DIANA, “User's manual.” TNO DIANA 10.2, BV, Delft, The Netherlands, 2017.

[32] NZS1170, "Structural Design Actions. Part 5: Earthquake actions. Standards New Zealand," 2004.

[33] J. R. Lester, A. G. Brown, and J. M. Ingham, "Stabilisation of the Cathedral of the Blessed Sacrament following the Canterbury earthquakes," Eng. Fail. Anal., vol. 34, pp. 648-669, Dec. 2013.

[34] B. A. Bradley, "Systematic Ground Motion Observations in the Canterbury Earthquakes And Region-Specific Non-Ergodic Empirical Ground Motion Modeling," Earthq. Spectra, vol. 31, no. 3, pp. 1735-1761, Aug. 2015.

[35] B. A. Bradley, "Ground motion and Seismicity Aspects of the 4 September 2010 Darfield and 22 February 2011 Christchurch Earthquakes," Christchurch, New Zealand, 2012.

[36] GeoNET, “Darfiel (Canterbury), September 4 2010.” [Online]. Available: http://www.geonet.org.nz/earthquake/historic-earthquakes/top-nz/quake-13.html.

[37] K. Gledhill, J. Ristau, M. Reyners, B. Fry, and C. Holden, "The Darfield (Canterbury, New Zealand) Mw 7.1 Earthquake of September 2010: A Preliminary Seismological Report," Seismol. Res. Lett., vol. 82, no. 3, pp. 378-386, May 2011. [38] “GeoNET DataBase, September 4 2010.” [Online]. Available: 
ftp://ftp.geonet.org.nz/strong/processed/Proc/2010/09_Darfield_mainshock_exten ded_pass_band/Vol2.

[39] J. M. Leite, N. Mendes, and P. B. Lourenço, "Ambient Modal Analysis of the Cathedral of the Blessed Sacrament, Christchurch, New Zealand," Rep. 11DEC/E-35, 2011.

[40] M. Anagnostopoulou, M. Bruneau, and H. P. Gavin, "Performance of churches during the Darfield earthquake of September 4, 2010," Bull. New Zeal. Soc. Earthq. Eng., vol. 43, no. 4, 2010.

[41] “GeoNET DataBase, February 22 2011." [Online]. Available: ftp://ftp.geonet.org.nz/strong/processed/Proc/2011/02_Christchurch_mainshock_ extended_pass_band/Vol2.

[42] J. Lester, A. Brown, and J. Ingham, "Christchurch Cathedral of the Blessed Sacrament : Lessons learnt on the Stabilisation of a Significant Heritage Building," in New Zealand Society for Earthquake Engineering Technical Conference, 2012, pp. $78-88$.

[43] D. Dizhur et al., "Performance of Masonry Buildings and Churches in the 22 February 2011 Christchurch Earthquake,” Bull. New Zeal. Soc. Earthq. Eng., vol. 44, no. 4, 2011.

[44] S. Weihe, B. Kröplin, and R. De Borst, "Classification of smeared crack models based on material and structural properties," Int. J. Solids Struct., vol. 35, no. 12, pp. 1289-1308, 1998.

[45] M. Giaretton, D. Dizhur, F. da Porto, and J. Ingham, "Constituent material properties of New Zealand unreinforced stone masonry buildings," J. Build. Eng., vol. 4, pp. 75-85, 2015.

[46] CEB-FIP, “Model Code 90," Thomas Telford Ltd., UK, 1993. 
[47] P. B. Lourenço, "Recent advances in masonry structures: Micromodelling and homogenisation," in Multiscale Modeling in Solid Mechanics, vol. 3, U. Galvanetto and M. H. F. Aliabadi, Eds. Imperial College Press, 2009, pp. 251-294.

[48] D. F. D'Ayala and S. Paganoni, “Assessment and analysis of damage in L'Aquila historic city centre after 6th April 2009," Bull. Earthq. Eng., vol. 9, no. 1, pp. 81104, Nov. 2010.

[49] H. Kaplan, H. Bilgin, S. Yilmaz, H. Binici, and A. Öztas, "Structural damages of L'Aquila (Italy) earthquake," Nat. Hazards Earth Syst. Sci., vol. 10, pp. 499-507, 2010.

[50] L. Sorrentino, L. Liberatore, L. D. Decanini, and D. Liberatore, "The performance of churches in the 2012 Emilia earthquakes," Bull. Earthq. Eng., vol. 12, no. 5, pp. 2299-2331, Sep. 2013.

[51] L. C. Silva, "Analysis of Christchurch Catholic Basilica, New Zealand," University of Minho. Integrated Master Thesis, 2013.

[52] D. D'Ayala and E. Speranza, "An integrated procedure for the assessment of seismic vulnerability of historic buildings," 12th European Conference on Earthquake Engineering. University of Bath, 16-Oct-2002.

[53] D. D'Ayala and E. Speranza, "Definition of Collapse Mechanisms and Seismic Vulnerability of Historic Masonry Buildings," Earthq. Spectra, vol. 19, no. 3, pp. 479-509, Aug. 2003.

[54] M. Skibeli, "Concrete Plates Designed with FEM," Norwegian University of Science and Technology, 2017.

[55] M. Jirásek, "Modeling of localized damage and fracture in quasibrittle materials," in Continuous and Discontinuous Modelling of Cohesive-Frictional Materials, P. A. Vermeer, H. J. Herrmann, S. Luding, W. Ehlers, S. Diebels, and E. Ramm, Eds. 
Berlin, Heidelberg: Springer Berlin Heidelberg, 2001, pp. 17-29.

820

[56] EN 1998-1, "Eurocode 8. Design provisions for earthquake resistance of structures. Part 1-1: General rules - seismic actions and general requirements for structures.," Brussels, Belgium Eur. Commitee Stand., 2004.

[57] Applied Technology Council (ATC), "Seismic evaluation and retrofit of concrete buildings," 1996.

[58] FEMA 356, "Prestandard and Commentary for the Seismic Rehabiliation of Buildings," Washington, DC, USA, 2000.

[59] 3274/2003 OPCM, Primi elementi in materia di criteri generali per la classificazione sismica del territorio nazionale e di normative tecniche per le costruzioni in zona sismica (in Italian). Rome, Italy, 2003.

[60] P. B. Lourenço, N. Mendes, L. F. Ramos, and D. V. Oliveira, “Analysis of Masonry Structures Without Box Behavior," Int. J. Archit. Herit., vol. 5, no. 4-5, pp. 369382, Jul. 2011.

[61] A. K. Chopra, Dynamics of structures: theory and applications to earthquake engineering. Pearson Prentice Hall, 2017.

[62] S. Antoniou and R. Pinho, "Advantages and limitations of adaptive and nonadaptive forc-based pushover procedures," J. Earthq. Eng., vol. 8, no. 4, pp. 497$522,2004$.

[63] NZSEE, “The Seismic Assessment of Existing Buildings - Technical Guidelines for Engineering Assessments,” New Zealand, 2017.

[64] A. K. Chopra and R. K. Goel, "A modal pushover analysis procedure to estimate seismic demands for unsymmetric-plan buildings," Earthq. Eng. Struct. Dyn., vol. 33, no. 8, pp. 903-927, 2004.

[65] G. Karanikoloudis and P. B. Lourenço, "Structural assessment and seismic 
vulnerability of earthen historic structures. Application of sophisticated numerical and simple analytical models," Eng. Struct., vol. 160, pp. 488-509, 2018.

[66] M. P. Ciocci, S. Sharma, and P. B. Lourenço, "Engineering simulations of a supercomplex cultural heritage building: Ica Cathedral in Peru," Meccanica, vol. 53, no. 7, pp. 1931-1958, 2018.

[67] G. Milani and M. Valente, "Failure analysis of seven masonry churches severely damaged during the 2012 Emilia-Romagna (Italy) earthquake: Non-linear dynamic analyses vs conventional static approaches," Eng. Fail. Anal., vol. 54, pp. 13-56, 2015.

[68] G. A. Cundari, G. Milani, and G. Failla, "Seismic vulnerability evaluation of historical masonry churches: Proposal for a general and comprehensive numerical approach to cross-check results," Eng. Fail. Anal., vol. 82, pp. 208-228, 2017.

[69] A. J. Papazoglou and A. S. Elnashai, "Analytical and field evidence of the damage effect of vertical earthquake ground motion,” Earthq. Eng. Struct. Dyn., vol. 25, no. 10, pp. 1109-1137, Dec. 1998.

[70] H.-B. Hellwega and M. A. Crisfield, "A new arc-length method for handling sharp snap-backs," Comput. Struct., vol. 66, no. 5, pp. 704-709, Mar. 1998.

[71] V. Elizabeth and T. T. P., "Three-Leaf Stone Masonry Strengthened by Injecting Cement Grouts,” J. Struct. Eng., vol. 121, no. 5, pp. 848-856, May 1995.

[72] M. R. Valluzzi, L. Binda, and C. Modena, "Mechanical behaviour of historic masonry structures strengthened by bed joints structural repointing," Constr. Build. Mater., vol. 19, no. 1, pp. 63-73, 2005.

[73] F. Ceroni, M. Pecce, S. Voto, and G. Manfredi, "Historical, Architectural, and Structural Assessment of the Bell Tower of Santa Maria Del Carmine," Int. J. Archit. Herit., vol. 3, no. 3, pp. 169-194, Apr. 2009. 
[74] S. Frumento, S. Giovinazzi, S. Lagomarsino, and S. Podestà, "Seismic Retrofitting of Unreinforced Masonry Buildings in Italy," in NZSEE conference, 2006.

[75] D. Dizhur, S. Bailey, M. Griffith, and J. Ingham, "Earthquake Performance of Two Vintage URM Buildings Retrofitted Using Surface Bonded GFRP: Case Study,” J. Compos. Constr., vol. 19, no. 5, p. 5015001, Oct. 2015.

[76] S. Bailey, D. Dizhur, J. Trowsdale, M. Griffith, and J. M. Ingham, "Performance of Posttensioned Seismic Retrofit of Two Stone Masonry Buildings during the Canterbury Earthquakes," J. Perform. Constr. Facil., vol. 29, no. 4, p. 4014111, Aug. 2015.

[77] Ministry for Cultural Heritage and Activities, Guidelines for evaluation and mitigation of seismic risk to cultural heritage. 2007.

[78] Steel structures standard: Parts 1 and 2. 1997.

[79] ACI 530, Building Code Requirements for Masonry Structures (ACI 530-05). Masonry Standars Joint Comittee. 2005.

[80] P. B. Lourenço, Â. Melo, and M. Carneiro, "Remedial measures for Cathedral of Porto : a post-modern conservation approach," in Proceedings of the IVth Int. Seminar on Structural Analysis of Historical Constructions, 2004. 
Table 1 - Material parameters of the numerical model.

\begin{tabular}{|c|c|c|c|c|c|c|c|}
\hline \multirow[b]{2}{*}{ Material } & \multirow[b]{2}{*}{$\begin{array}{c}\gamma \\
\left(\mathrm{kN} / \mathrm{m}^{3}\right)\end{array}$} & \multirow{2}{*}{$\begin{array}{c}\mathrm{E} \\
(\mathrm{GPa})\end{array}$} & \multirow[b]{2}{*}{$v$} & \multirow{2}{*}{$\begin{array}{l}\text { Compressive } \\
\text { strength } \\
\left(\mathrm{f}_{\mathrm{c}}\right)[\mathrm{kPa}]\end{array}$} & \multirow{2}{*}{$\begin{array}{l}\text { Tensile } \\
\text { strength } \\
\left(\mathrm{f}_{\mathrm{t}}\right)[\mathrm{kPa}]\end{array}$} & \multicolumn{2}{|c|}{ Fracture energy $[\mathrm{kN} / \mathrm{m}]$} \\
\hline & & & & & & $\begin{array}{c}\text { Compressive } \\
\left(\mathrm{G}_{\mathrm{fc}}\right)\end{array}$ & $\begin{array}{c}\text { Tensile } \\
\left(\mathrm{G}_{\mathrm{f}}\right)\end{array}$ \\
\hline Masonry & 20.0 & 2.00 & 0.15 & 8000 & 100 & 12.8 & 0.120 \\
\hline $\begin{array}{l}\text { RC (slabs } \\
\text { and beams) }\end{array}$ & 25.0 & 41.0 & 0.20 & 30000 & 2000 & 25.0 & 0.054 \\
\hline Steel & 78.0 & 200 & 0.25 & - & - & - & - \\
\hline Timber & 7.00 & 11.0 & 0.30 & - & - & - & - \\
\hline
\end{tabular}

889 


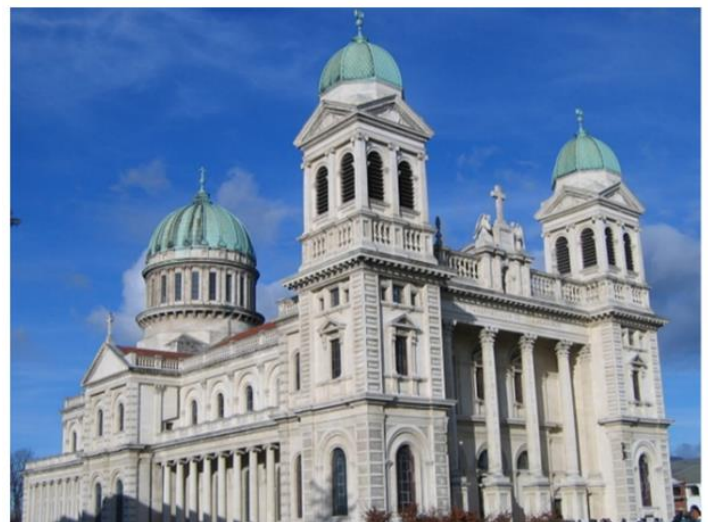

(a)

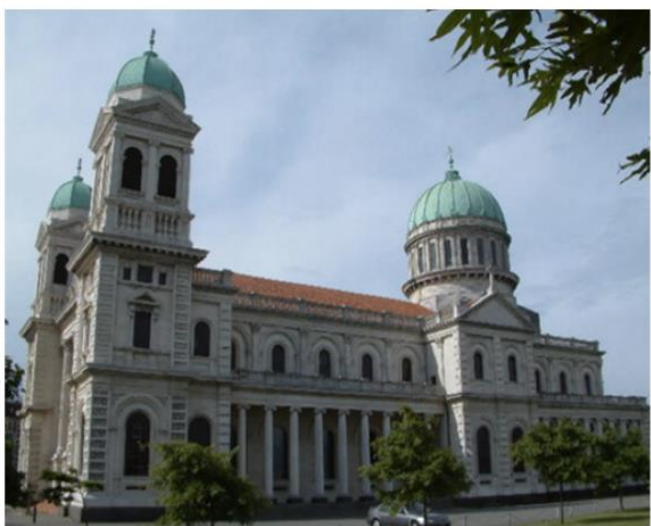

(b)

Fig. 1 - Cathedral of the Blessed Sacramento: (a) north and west façades; (b) south façade.

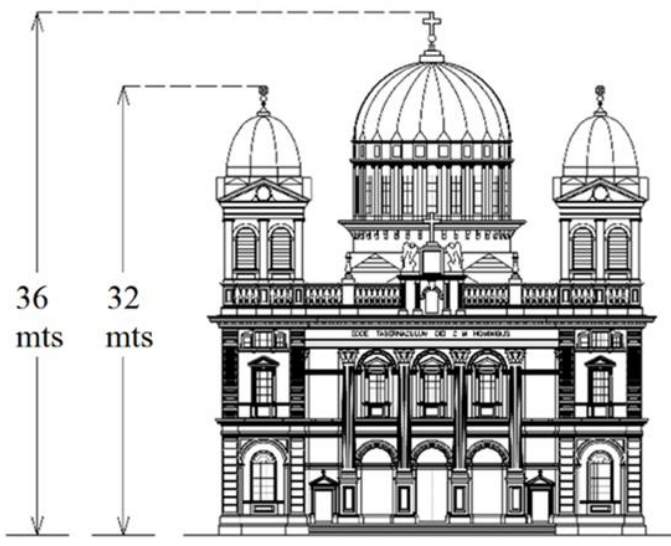

(a)

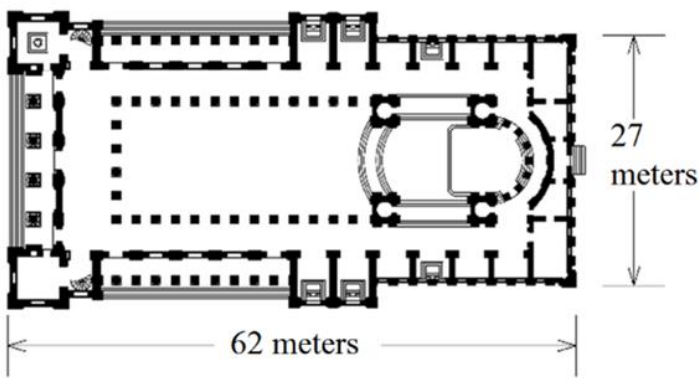

(b)

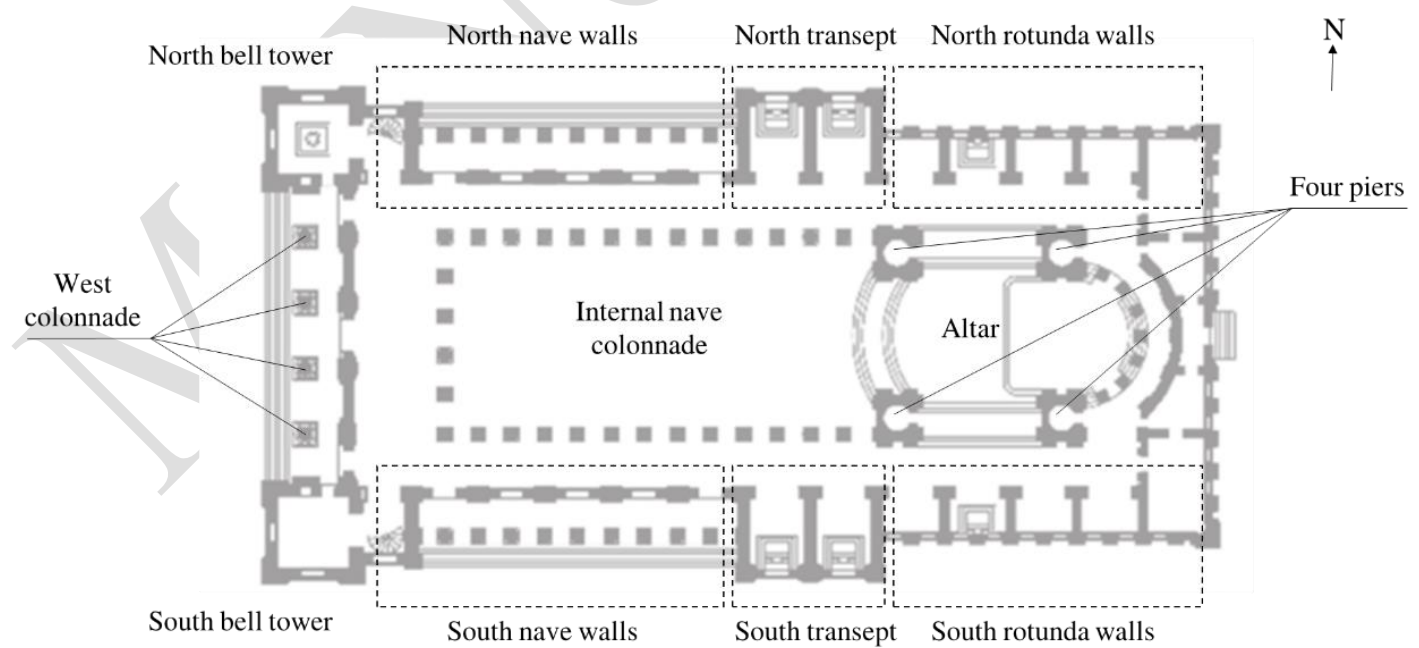

(c)

Fig. 2 - Geometry of Basilica of the Blessed Sacramento: (a) west elevation; (b) plan; (c) designation and location of important structural elements. 


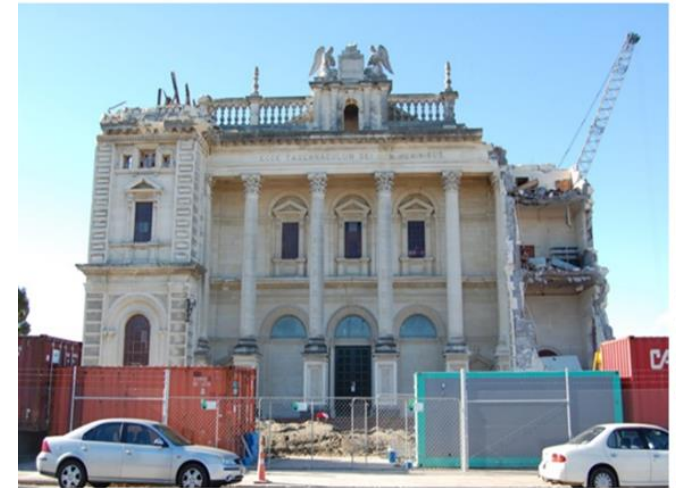

(a)

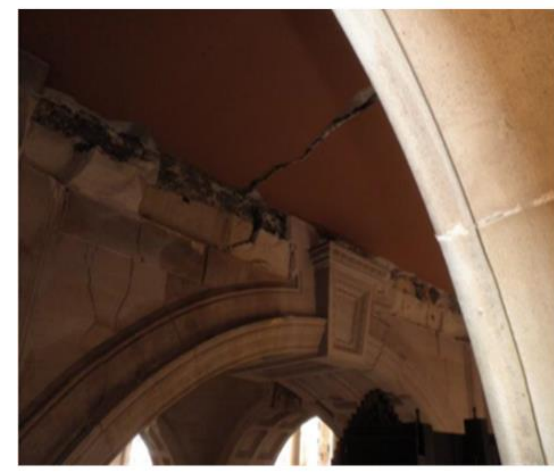

(d)

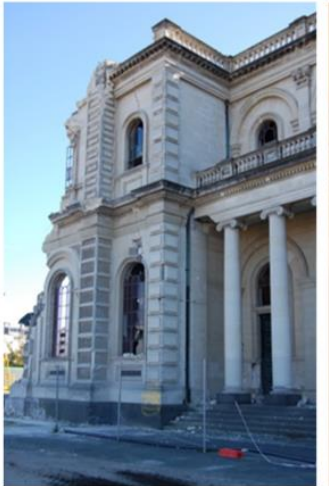

(b)

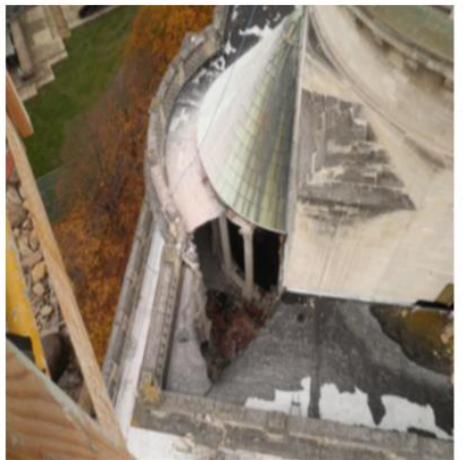

(e)

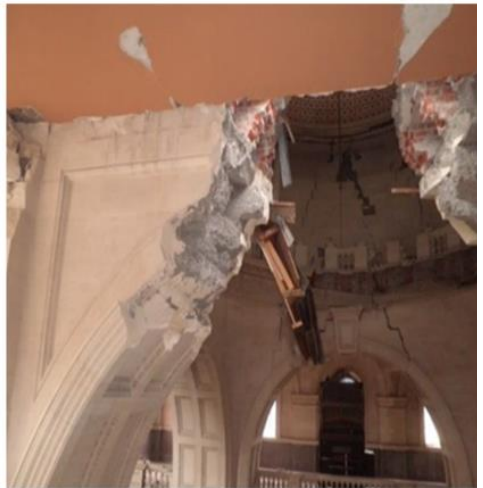

(c)

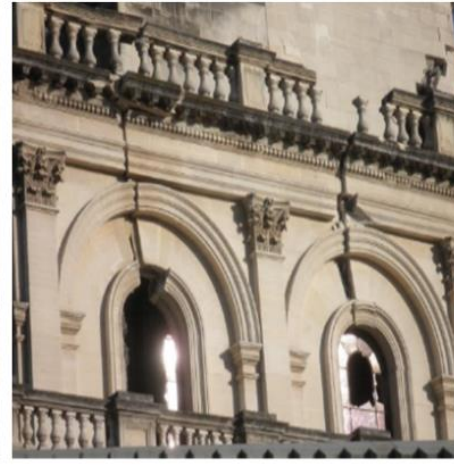

(f)

Fig. 3 - Observed damage in the Basilica after the February 2011 earthquake: (a) West façade, damage at the two bell towers; (b) Detail of the west wall collapse of the south bell tower; (c) Collapse in the north arch of the sanctuary; (d) Severe damage to the south arch spandrel; (e) Collapse of a part of the RC sanctuary flat roof; (f) Shear cracks around the upper arcade of the north elevation. 


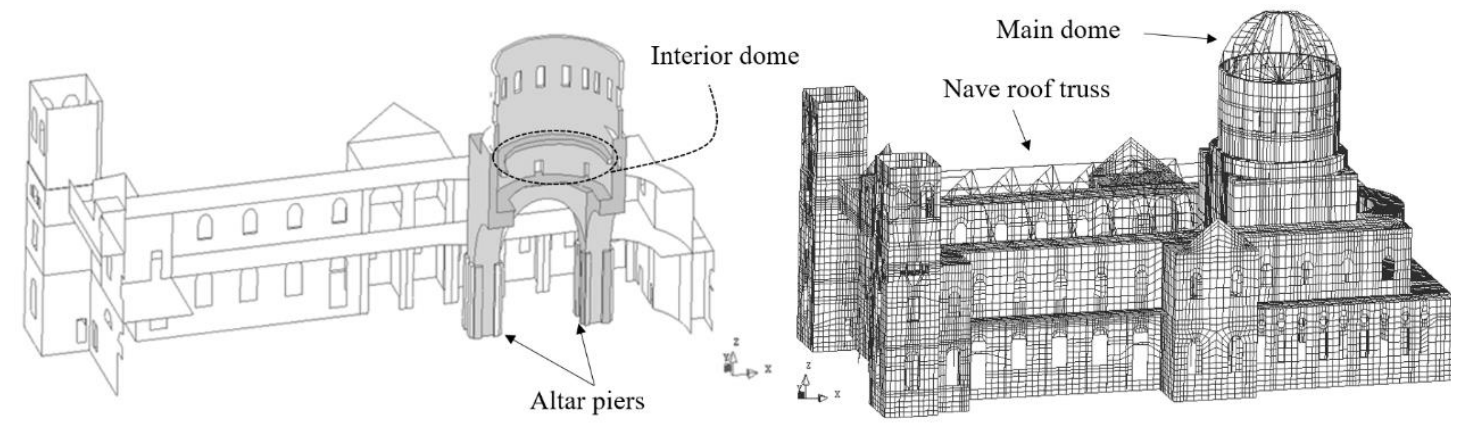

(a)

(b)

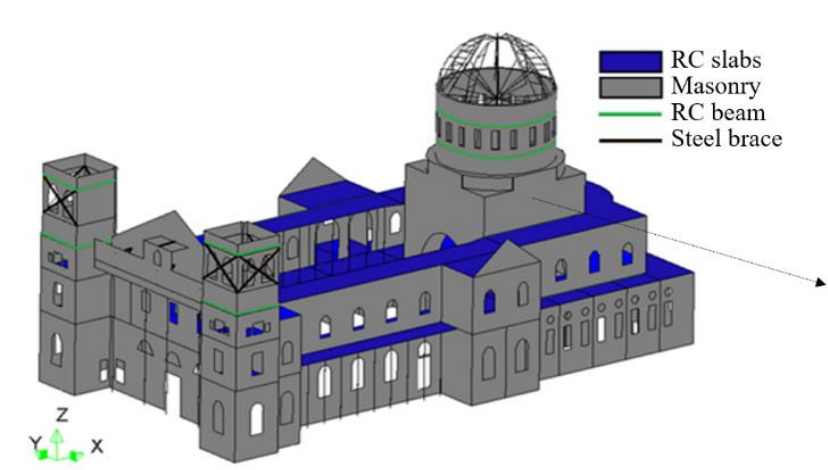

(c)

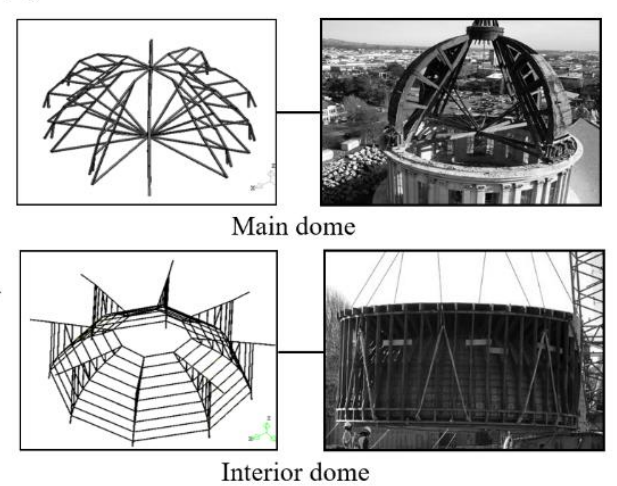

(d)

Fig. 4 - Three-dimensional model: (a) Shell and solid elements: west-east cut-away perspective with shell elements (coloured white) and solid elements (coloured grey); (b) Mesh discretization; (c) Description of the materials; (d) FE discretization of the main and interior dome.

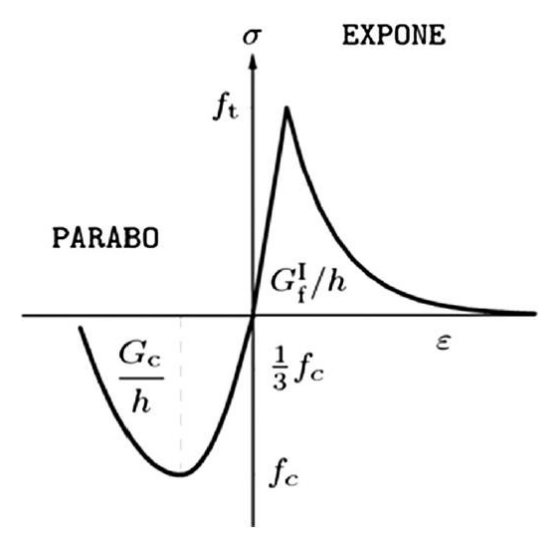

Fig. 5 - Stress and strain curves for the tension and compression regimes defined in the total strain fixed crack model [31]. 


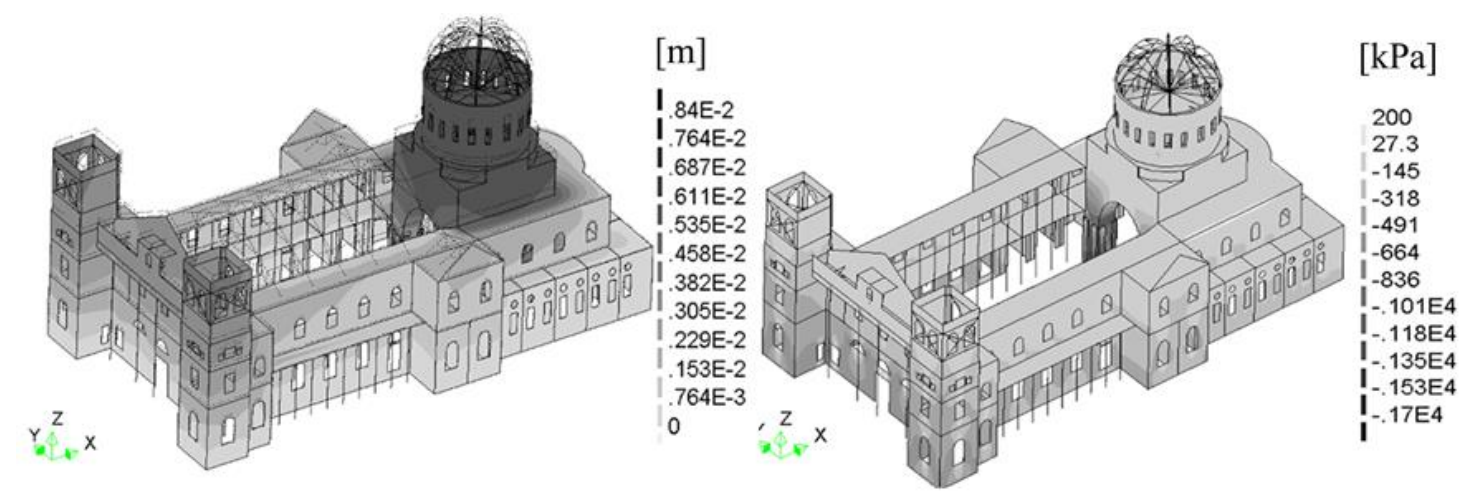

(a)

(b)

Fig. 6 - Results of the analysis due to the gravitational loads: (a) Total displacements; (b) Vertical stresses.

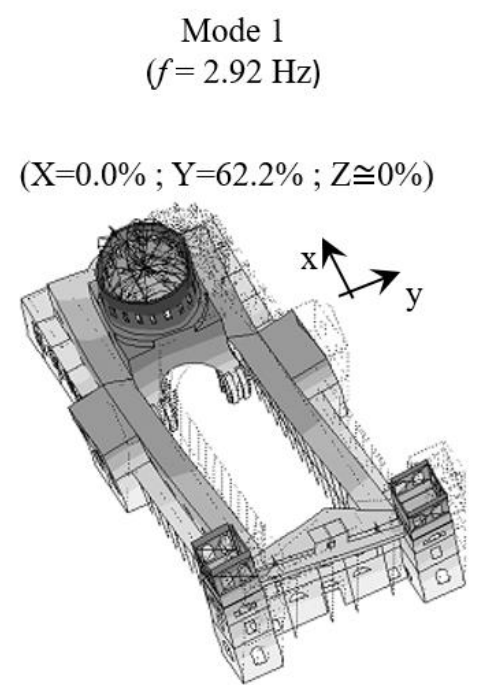

Mode 4 $(f=3.66 \mathrm{~Hz})$

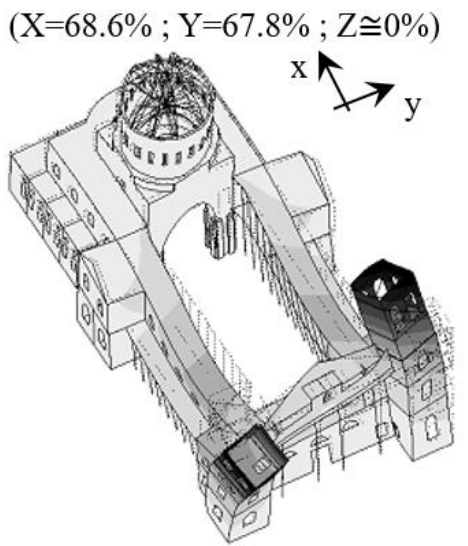

Mode 2

$(f=3.02 \mathrm{~Hz})$

Cumulative Mass Participation

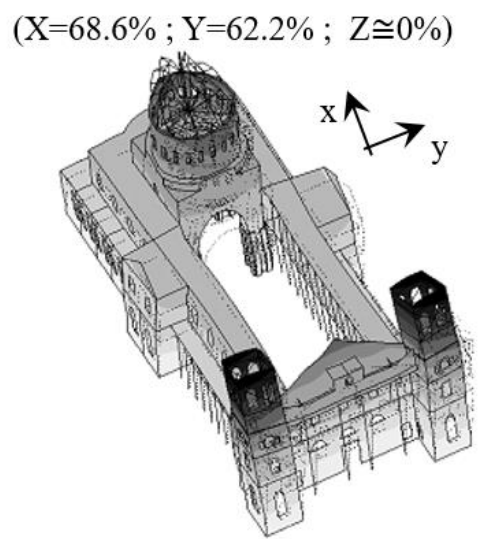

Mode 5

$(f=4.36 \mathrm{~Hz})$

Cumulative Mass Participation
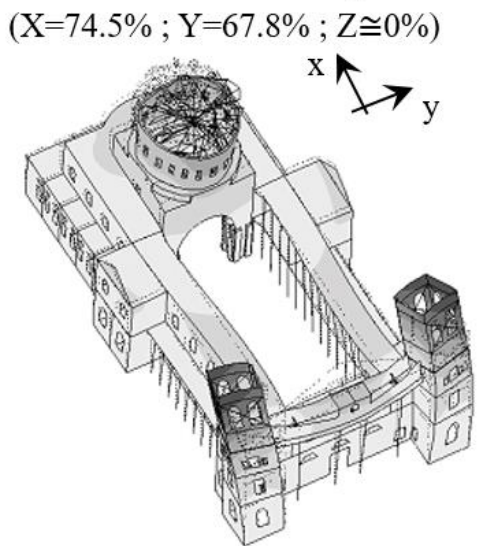

Mode 3

$(f=3.30 \mathrm{~Hz})$

$(X=68.6 \% ; Y=62.6 \% ; Z \cong 0 \%)$

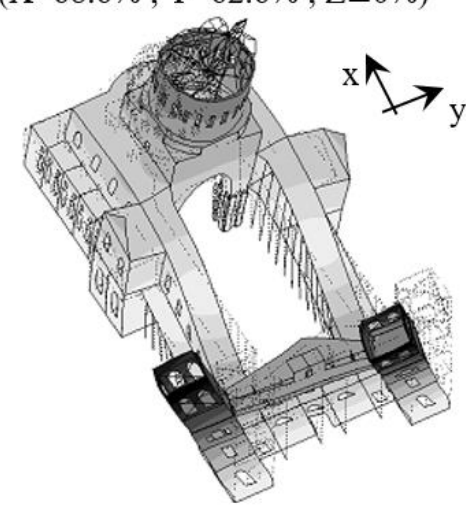

Mode 6

$(f=5.84 \mathrm{~Hz})$

$(\mathrm{X}=76.4 \% ; \mathrm{Y}=69.3 \% ; \mathrm{Z} \cong 0 \%)$

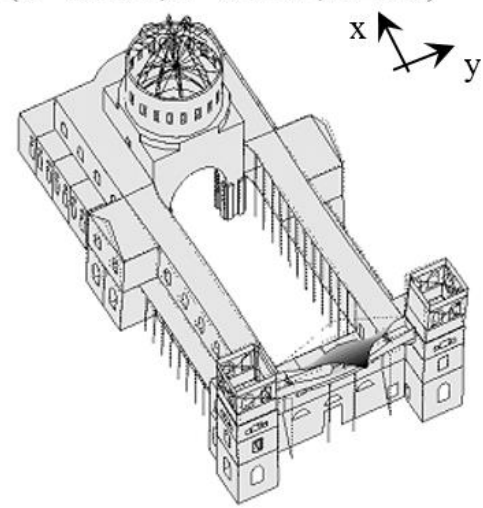

894 Fig. 7 - First six global mode shapes and cumulative mass participation for the non-damaged structure (the

895 roof truss beams are not depicted for clarity reasons). 

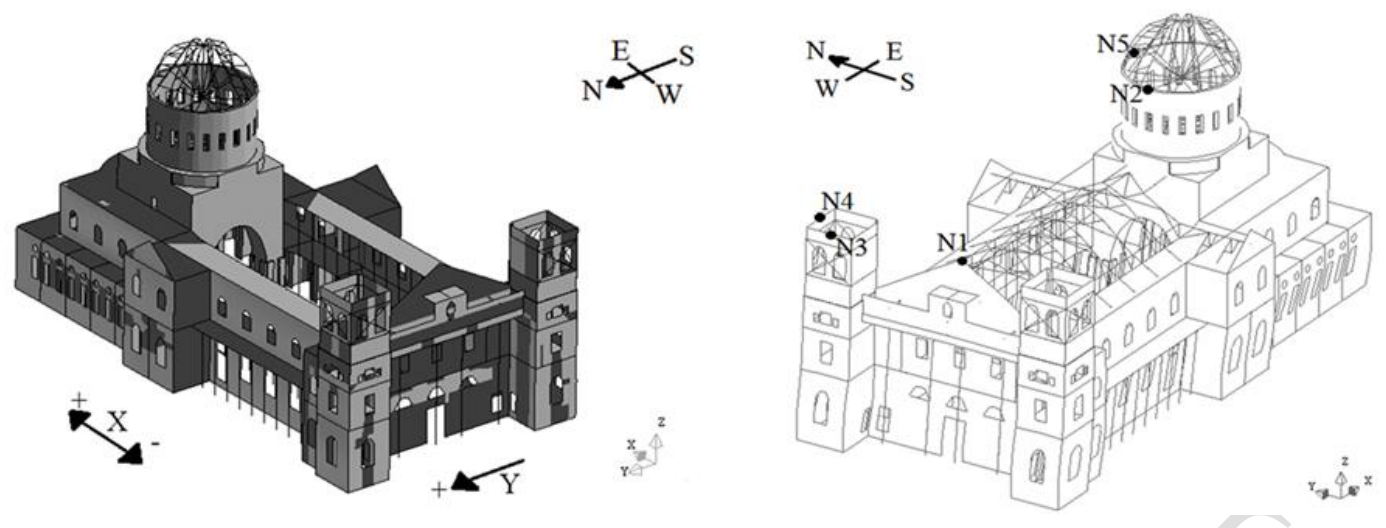

Fig. 8 - Directions and control nodes for the pushover analysis: (a) Applied load directions (longitudinal, $\mathrm{X}$; transversal, Y); (b) Control nodes used for evaluating the response of the structure.

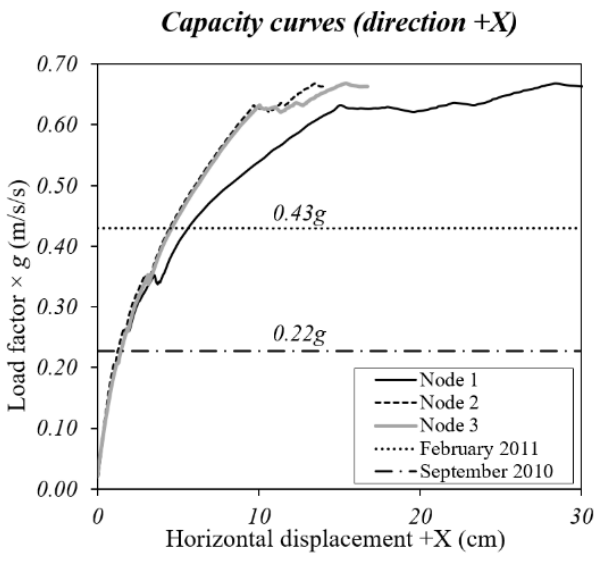

(a)

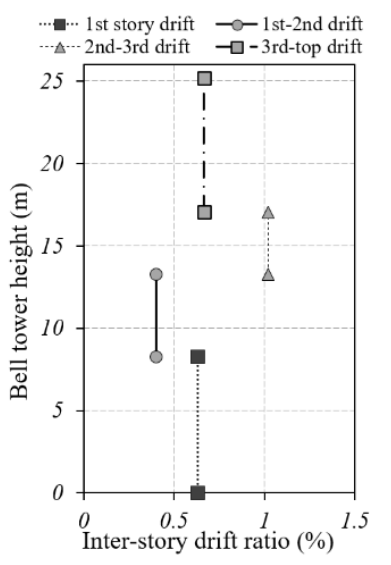

(b)

Fig. 9 - Pushover analysis in the longitudinal direction $+\mathrm{X}$ : (a) Capacity curves for control nodes 1, 2, and 3; (b) Inter-storey drifts ratio of the bell towers for the maximum load factor applied.

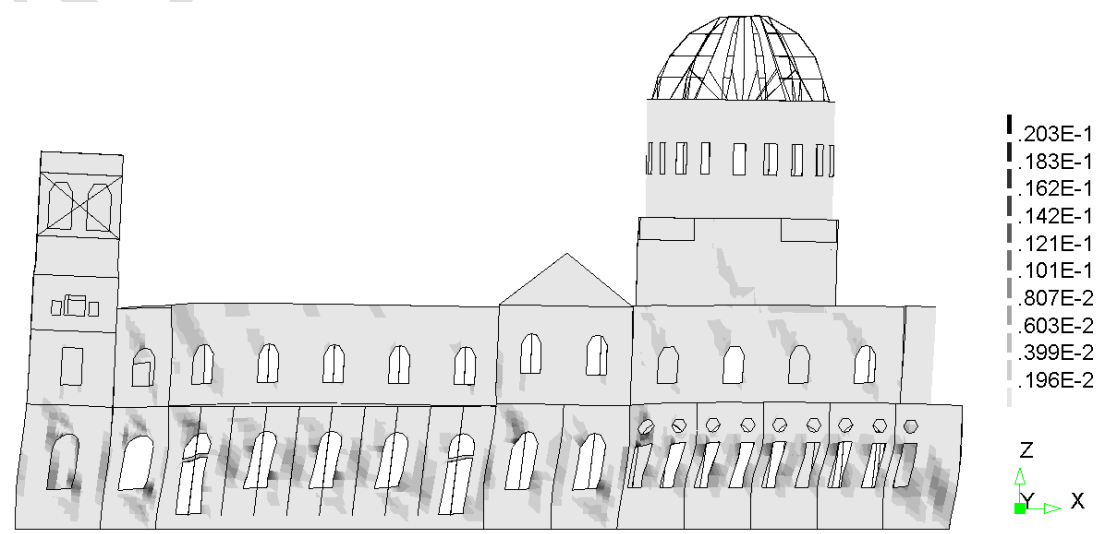

Fig. 10 - Principal tensile strains in the south façade walls for the pushover analysis in the longitudinal $+\mathrm{X}$ direction (February 2011 earthquake, $0.43 \mathrm{~g}$ ). (The nave roof frame is not represented). 


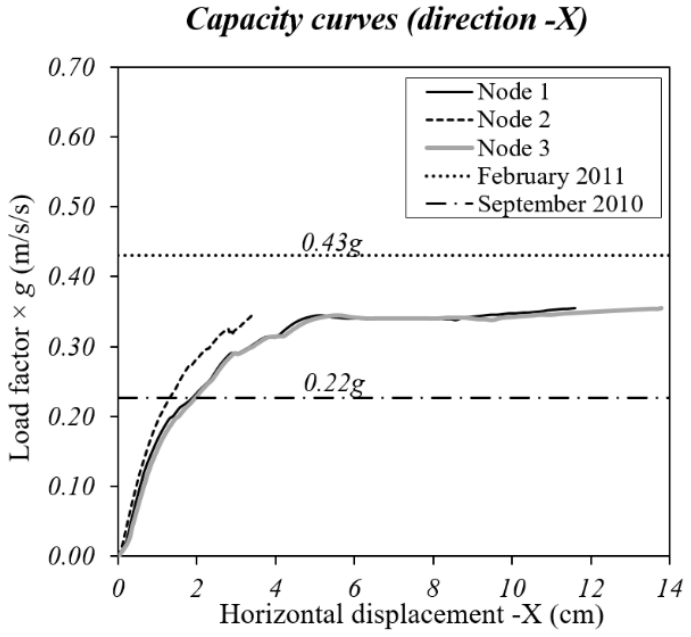

(a)

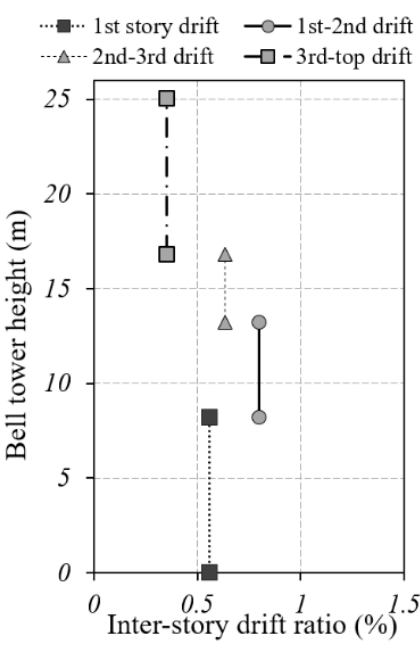

(b)

Fig. 11 - Pushover analysis in the longitudinal direction -X: (a) Capacity curves for control nodes 1, 2, and 3; (b) Inter-storey drifts ratio of the bell towers for an applied load factor equal to $0.35 \mathrm{~g}$.

899

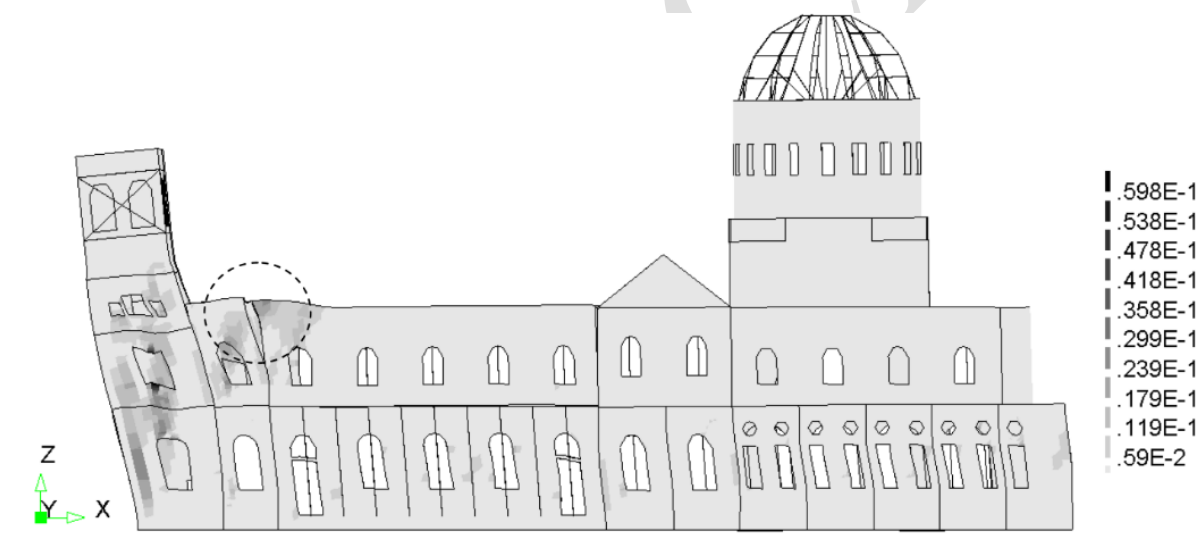

Fig. 12 - Principal tensile strains at the south façade walls for the pushover analysis in the longitudinal $\mathrm{X}$ direction $(0.35 \mathrm{~g})$. (The nave roof frame is not represented). 


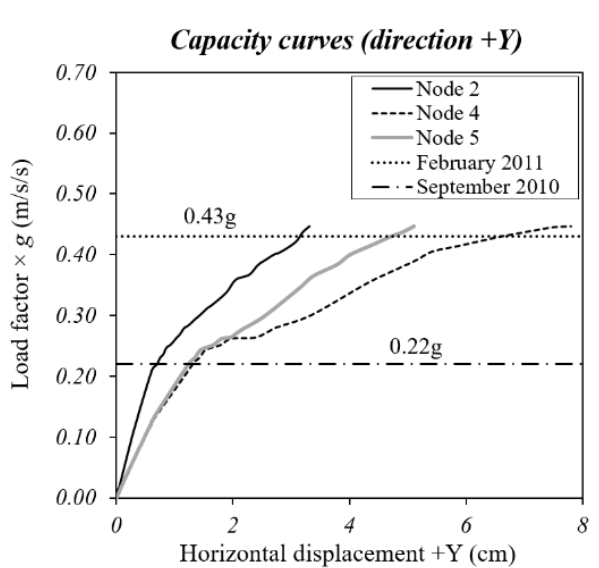

(a)

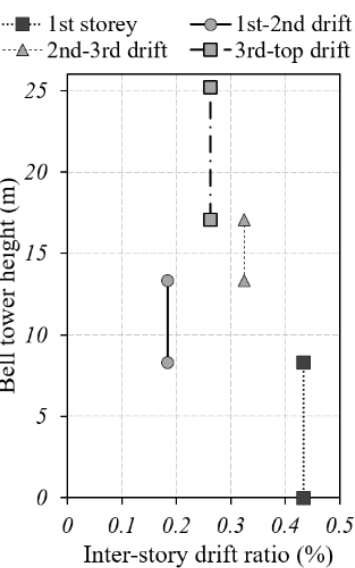

(b)

Fig. 13 - Pushover analysis in the transversal direction +Y: (a) Capacity curves for control nodes 2, 4, and 5; (b) Inter-story drifts ratio of the north bell tower for an applied load factor equal to $0.45 \mathrm{~g}$.

901

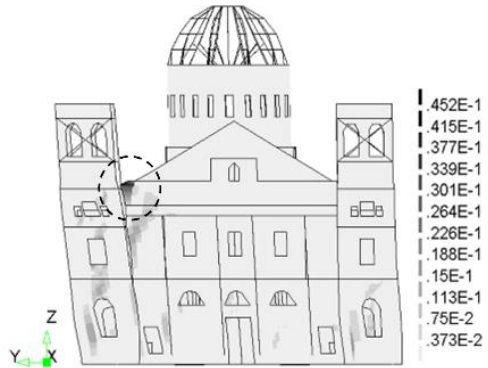

(a)

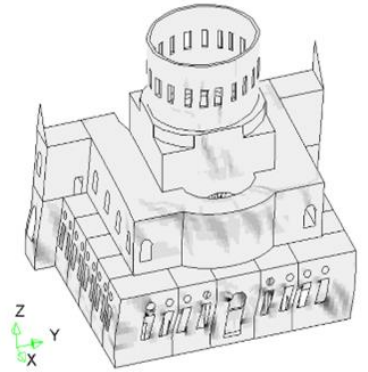

(b)

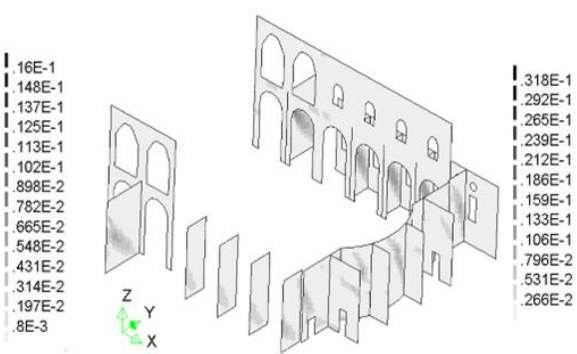

(c)

Fig. 14 - Principal tensile strains for the pushover analysis in the transversal direction $+Y$ for a horizontal load equal to $0.45 \mathrm{~g}$ (approximately equal to the PGA of the February 2011 earthquake): (a) West façade;

(b) East façade, rotunda, main dome and exterior slabs; (c) Damage to the interior transverse walls. 


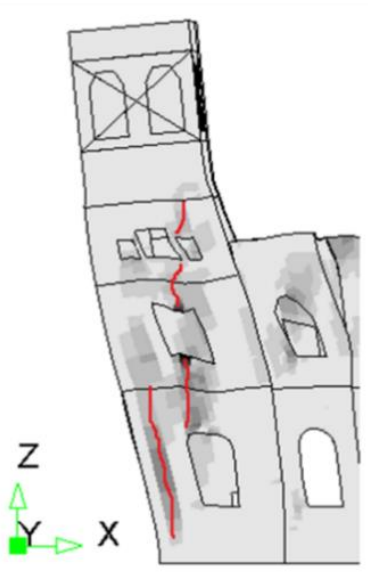

(a)

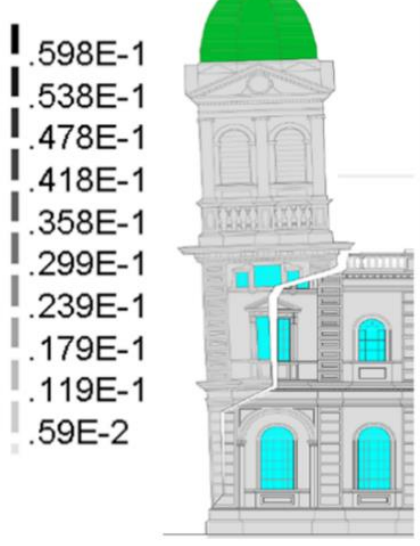

(b)

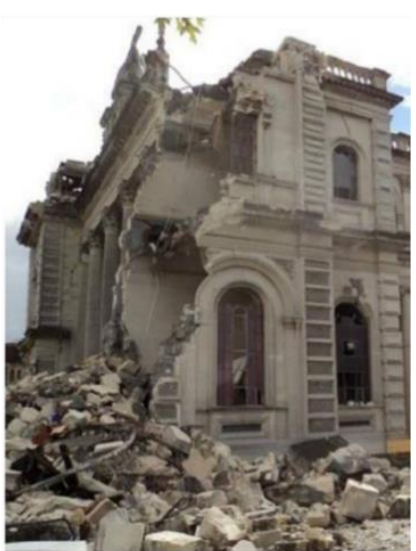

(c)

Fig. 15 - Bell towers failure mechanism: (a) Numerical damage for the horizontal load equal to $0.35 \mathrm{~g}$ ($\mathrm{X}$ direction); (b) and (c) Failure mechanism observed after the collapse of the south bell tower.
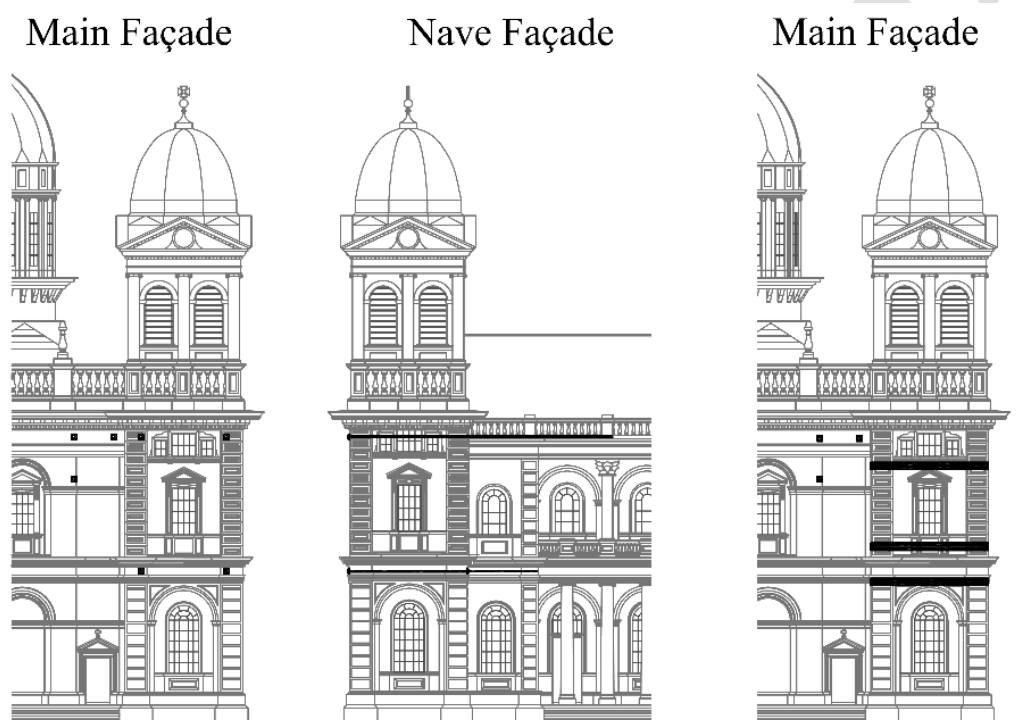

Nave Façade

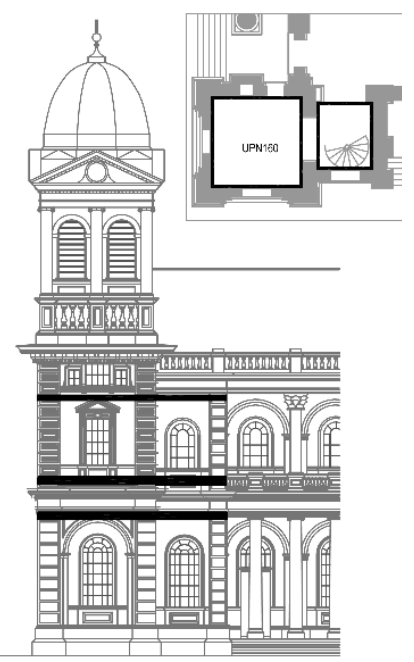

Fig. 16 - Strengthening proposals: (a) First proposed intervention with stainless steel tie rods; (b) Second proposed intervention with steel ring beams and three tie rods at the main façade. 


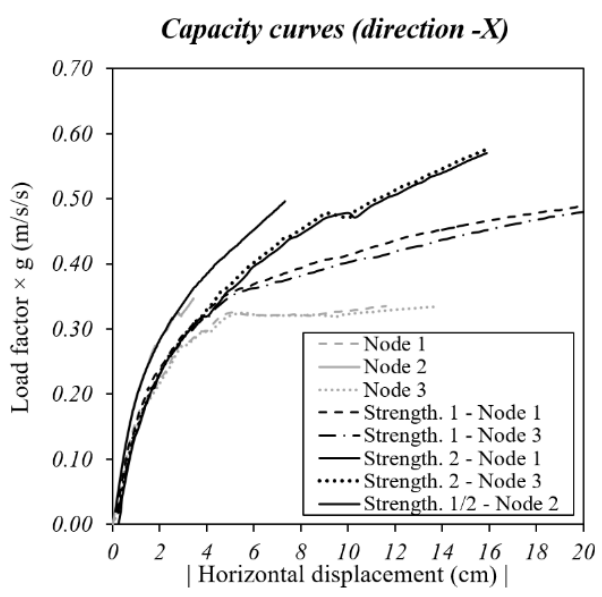

(a)

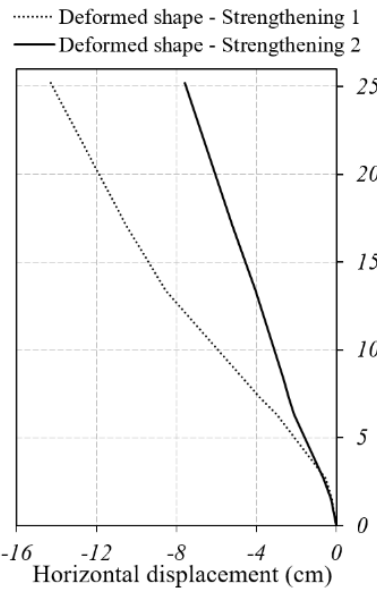

(b)

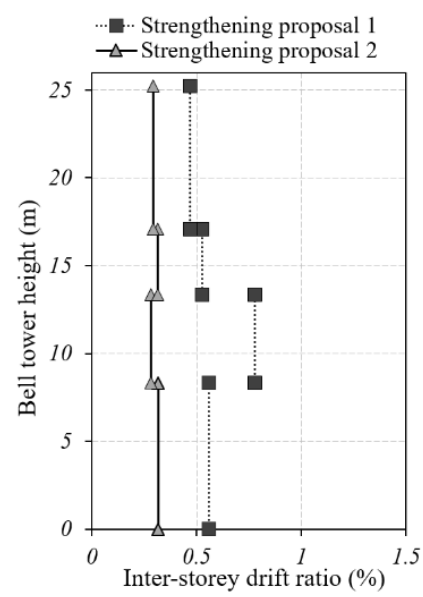

(c)

Fig. 17 - Strengthening proposals: (a) Obtained capacity curves; (b) Deformed shape at the south bell tower for a horizontal load equal to $0.43 \mathrm{~g}$; (c) Inter-story drifts ratio at the south bell tower for an applied load factor equal to $0.43 \mathrm{~g}$.

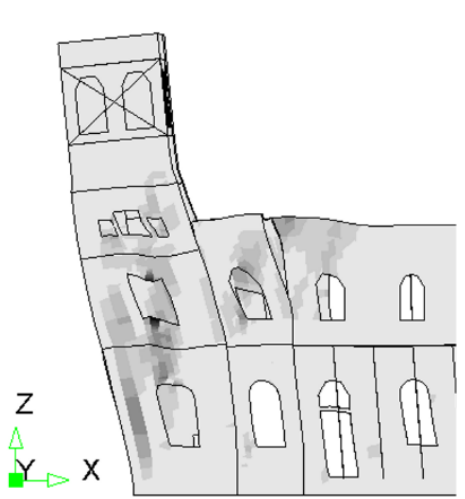

(a)

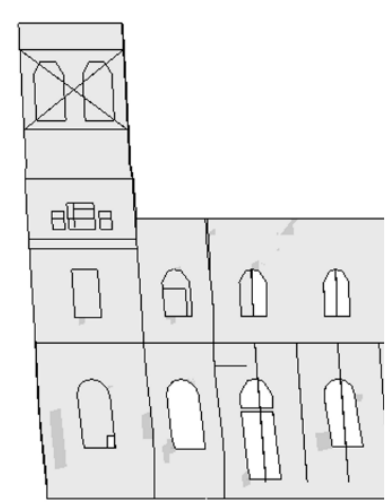

(b)

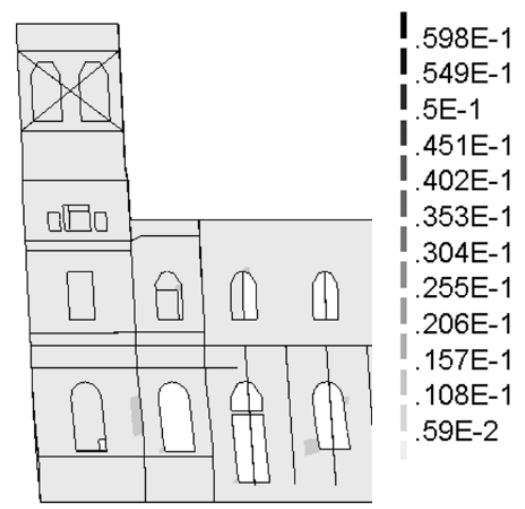

(c)

Fig. 18 - Comparison of principal tensile strains for the horizontal load equal to $0.35 \mathrm{~g}$ : (a) Nonstrengthened model; (b) Strengthened model 1; (c) Strengthened model 2. 


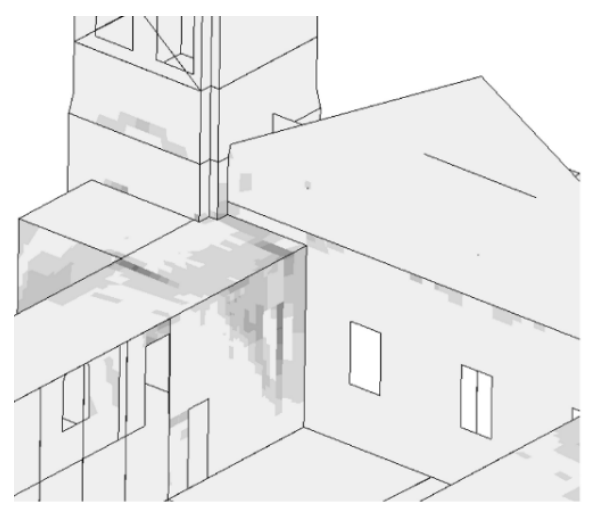

(a)

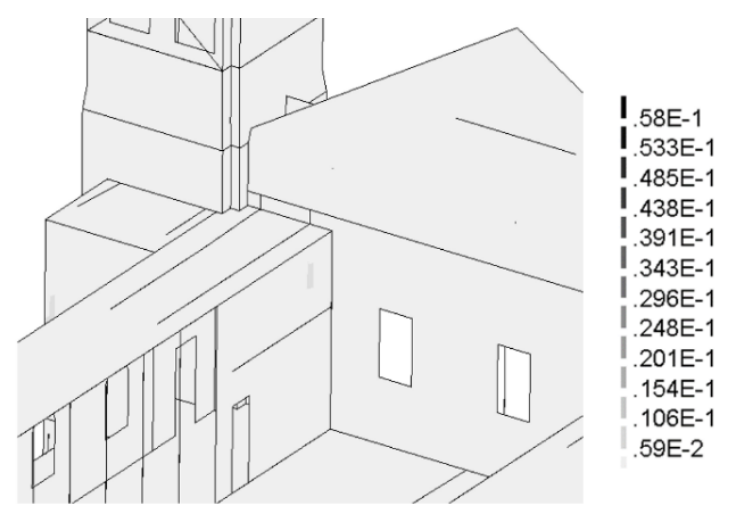

(b)

907 Fig. 19 - Details of the principal tensile strains for the horizontal load equal to $0.35 \mathrm{~g}$ : (a) Non-strengthened

908 model; (b) Strengthened model 1.

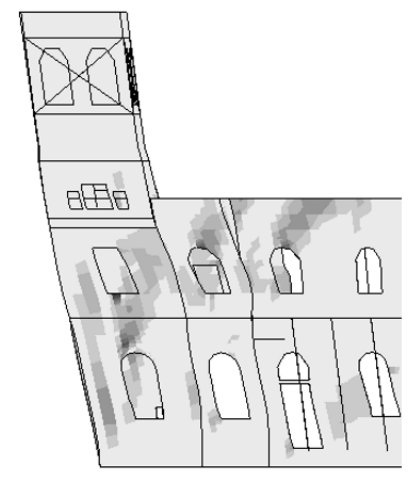

(a)

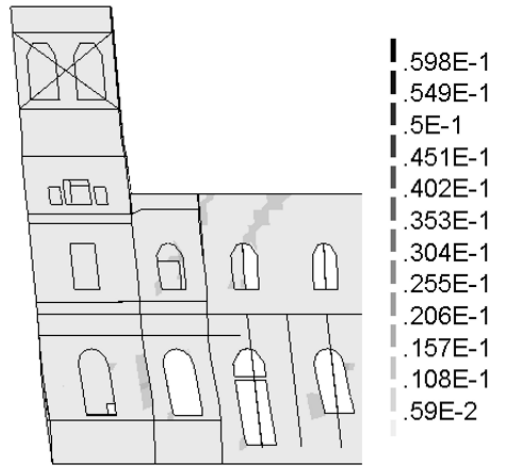

(b)

909 Fig. 20 - Comparison of principal tensile strains for the horizontal load equal to 0.43 g: (a) Strengthened

$910 \quad$ model 1; (b) Strengthened model 2. 